\title{
Tuna nutrition and feeds: current status and future perspectives
}

\author{
G. Mourente ${ }^{1}$ and D. R. Tocher ${ }^{2}$ \\ ${ }^{1}$ Dept. of Biology, Faculty of Marine and Environmental Sciences, University of Cadiz, \\ 11510-Puerto Real (Cadiz), Spain. \\ ${ }^{2}$ Institute of Aquaculture, University of Stirling, Stirling FK9 4LA, Scotland, U.K.
}

Running title: Tuna nutrition

Key words: Tuna; Nutrition; Requirements; Feeds; Scombrids; Tunids

\begin{abstract}
Abbreviations: ARA, arachidonic acid; ADC, apparent digestibility coefficient; CCK, cholesystokinin; DAH, days after hatch; DHA, docosahexaenoic acid; DNA, deoxyribonucleic acid; EFA, essential fatty acids; EPA, eicosapentaenoic acid; FAA, free amino acids; FCR, feed conversion ratio; GE, gross energy; lc-PUFA, long-chain polyunsaturated fatty acids; LOA, linoleic acid; LNA, $\alpha$-linolenic acid; NBT, Atlantic northern bluefin tuna (Thunnus thynnus); PBT, Pacific bluefin tuna (Thunnus orientalis); PUFA, polyunsaturated fatty acids; RMR, routine metabolic rate; RNA, ribonucleic acid; SBT, southern bluefin tuna (Thunnus maccoyii); SDA, specific dynamic action; SMR, standard metabolic rate; TAG, triacylglycerol; YFT, yellowfin tuna (Thunnus albacares).
\end{abstract}




\section{ABSTRACT}

Aquaculture is providing an ever-increasing proportion of fish in the human food basket prompting a search for new species to expand the range available to consumers. Large tunids/scombrids have long-since been a very valuable resource providing not only high quality protein, but also a rich source of the highly beneficial omega-3 (or n-3) long-chain polyunsaturated fatty acids including eicosapentaenoic and, especially docosahexaenoic acids in the human diet. Consequently, there is considerable interest worldwide in developing the culture of large tunids, including Atlantic northern bluefin tuna (Thunnus thynnus), Pacific bluefin tuna (Thunnus orientalis), southern bluefin tuna (Thunnus maccoyii) and yellowfin tuna (Thunnus albacares). Nutrition is vital to this development, playing key roles in reproductive success, including the establishment of successful broodstock producing high quality eggs and larvae, and ultimately the cost-effective production of nutritious seafood. This review summarises the rather fragmentary data that compromise the current state-of-theart in relation to tuna nutrition and the development of artificial, formulated feeds for these species. In highlighting the various considerable challenges that feed development will pose, we discuss the future perspectives for tuna culture in terms of both fish and human nutrition and welfare, against the background of diminishing global marine resources. 


\section{INTRODUCTION}

There have been several attempts at the domestication of large tunids and scombrids, but in these studies, and in the several capture base-farming schemes currently in operation around the globe, nutritional studies have been few (Glencross et al., 2002). In consequence, little is known about the quantitative or, indeed, qualitative, nutritional requirements for these species. However, nutritional factors will be crucial in a variety of key areas in any domestication programme. Correct and balanced nutrition is a vitally important factor in the establishment of successful broodstock with high fecundity and fertility producing large numbers of high quality eggs. Indeed, reproductive control is itself affected by nutritional factors including dietary energy content, protein/energy ratios and lipid/fat levels, which can influence sexual maturation in other fish species (Izquierdo et al., 2001; Watanabe and Vassallo-Agius, 2003). Successful larval rearing of marine fish is highly dependent upon suitable diets, whether live prey species or artificial, and their precise composition particularly in relation to long-chain polyunsaturated fatty acids (lc-PUFA) is an area that continues to demand much research for all marine species. Given the paucity of experimental evidence, clues to the nutritional requirements may be obtained by investigating the natural food of the animal, in this instance, the natural prey species of tunids and also by determining the composition of wild caught animals, both prey and predator. In this review, we have used this approach along with the existing knowledge of other marine species, and the few data emerging from experimental trials with tunids, to develop an overall view of the likely requirements of large tunids for both macro- and micronutrients. We will also briefly review the literature on nutrition at key periods in ontogeny such as in broodstock and larvae, and recent advances in the development of artificial feeds and feeding practices. Glencross et al. (2007) recently highlighted that "a feed is only as good as its ingredients" and, consequently, 
a fish can only be as good as its feed. Therefore, most importantly, we attempt to place the very significant problems associated with the successful development of large-scale culture of large tunids, and their feeding and nutrition, in a global perspective of diminishing marine resources.

\section{COMPOSITION OF TUNIDS AND THEIR PREY SPECIES}

\subsection{Body composition of wild tuna}

The body composition of wild tuna may give some indication of possible dietary requirements, at least in respect of lipid content and fatty acid composition. Clearly, there can be great variation in carcass fat levels reflecting condition factors that are almost certainly related to season. In contrast, the protein composition was observed to be less variable. The very strong inverse relationship between body fat and water in Atlantic northern bluefin tuna (NBT, Thunnus thynnus) indicated that the fish obtain energy for their migrations from muscle lipid reserves (Clay, 1988). The fact that flesh lipid levels can vary so widely has important consequences for farming. The level of fat in the flesh will be partly dependent upon dietary fat levels, but seasonal factors affecting the metabolism of lipids in the fish may also be important. The potential benefits of high fat diets such as rapid growth may have to be balanced with potential deleterious effects such as reduced product quality and consumer acceptance.

The polyunsaturated fatty acid (PUFA) compositions of most marine fish are dominated by the n-3 lc-PUFA, eicosapentaenoic (EPA; 20:5n-3) and docosahexaenoic (DHA; 22:6n-3) acids (Sargent et al., 2002). However, the fatty acid compositions of tuna species appear unique in that they are characterised by relatively high levels of DHA and, 
especially, a very high DHA:EPA ratio (Sawada et al., 1993). This ratio seldom exceeds 2 in the lipids of northern hemisphere marine fish but, in the southern hemisphere, the lipids of marine fish generally show higher EPA levels and consequently even lower DHA:EPA ratios (Ackman, 1980). In contrast, Pacific bluefin tuna (PBT, Thunnus orientalis) showed flesh DHA levels of between $25 \%$ and $36 \%$ with DHA:EPA ratios of up to 6, whereas the stomach contents showed a DHA:EPA ratio of just over 3 (Ishihara and Saito, 1996), and NBT displayed DHA:EPA ratios in muscle phospholipids of over 7 (Medina et al., 1995). Murase and Saito (1996) studied the lipid and fatty acid content in different organs (dorsal muscle, ventral muscle, dark muscle, liver, heart, pyloric caeca, orbital oil and stomach content) of albacore (Thunnus alalunga) and found DHA:EPA ratios ranging from 3.0 in liver to 6.6 in heart, and DHA levels were in all cases above $25 \%$ of total fatty acids in weight percentage. Therefore, the relatively high DHA and the high DHA:EPA ratio appears to be a characteristic of tuna species that may have to be reproduced in farmed fish to preserve the qualities that the consumer would expect.

\subsection{Prey species}

Tunas are considered as mid-water meso-carnivorous pursuers or large predatory fishes that feed on smaller fishes, squids and other nektonic prey in mid-water. However, the food spectrum for tuna changes during ontogeny with larvae feeding primarily on small zooplankton, mainly copepods and copepoda nauplii (Uotani et al., 1990). Specifically, PBT larvae in the northern Pacific were shown to feed on zooplankton, including copepod nauplii, calanoids, cyclopods, cladocerans and corycaeids (Uotani et al., 1981, 1990; Young and Davis, 1990), whereas juveniles and adults are opportunistic feeders. Thus, juvenile PBT feed on crustaceans, fish and cephalopods, while adults feed predominantly on fish (herring 
Clupea harengus, sand lance Ammodytes spp,, bluefish Pomatomus saltatrix, mackerel Scomber scombrus and various anchovy, sardine and sprat species). Changes in diet and trophic levels in relation to size have also been found in Mediterranean NBT. The contribution to the diet of different prey was highlighted for each class, and NBT from small juveniles to large adults showed a shift in feeding preferences due to different use of habitats and food items as a function of the life stage, and the trophic level of tuna belonging to each size class was closely correlated to weight (Sara and Sara, 2007). Therefore, as with PBT, the diet of juvenile NBT comprised zooplankton, small pelagic fish and some coastal fish whereas sub-adults relied on medium pelagic fish, shrimps and cephalopods, and adults consumed mainly cephalopods and larger fish (Sara and Sara, 2007). In an earlier study, immature NBT in the Bay of Biscay consumed fish (anchovy) $>$ crustaceans (euphausids) $>$ cephalopods by frequency of occurrence, and crustaceans $>$ fish $>$ cephalopods by numerical frequency, with anchovy as the most important prey species (Ortiz de Zarate and Coll, 1986). The diet of juvenile (young of the year) NBT caught off the coast of Sicily, deduced from the frequency of the items found in their stomachs, was primarily fish (found in stomachs of $85 \%$ of sampled NBT), followed by crustaceans (55\%) and cephalopods (51\%) (Sinopoli et al., 2004).

There are many reports on the prey species of adult NBT based on the examination of gut contents (Dragovich, 1970; Holliday, 1978; Eggleston and Bochenek, 1990; Young et al., 1997; Chase, 2002). The stomach contents of NBT in the Mediterranean (Ligurian Sea) were dominated by anchovies, although mesopelagic fish, crustaceans and ommastrephid cephalopods were also present (Orsi-Relini et al., 1995). Spatial variation in prey has been found to be the primary influence on NBT distribution during seasonal feeding migrations on the New England continental shelf, where sand lance, Atlantic herring, Atlantic mackerel, 
squid (Cephalopoda), and bluefish were the top prey in terms of frequency of occurrence and percent prey weight (Chase, 2002).

\section{DEFINITION OF BASIC NUTRITIONAL REQUIREMENTS OF TUNIDS}

The costs of research with the large bluefin tuna species are extremely high, associated with having to maintain operations of numerous sea cages, boats, crews and related infrastructure. Moreover, the difficulties associated with conducting structured and properly replicated trials with these species has prevented the determination of nutritional requirements by means of standard dose-response techniques (Glencross et al., 1999a, b). As a consequence, relative requirements have to be estimated on the modelling of performance of bluefin tunas fed various practical diet formulations. This approach can provide useful insights that can be applied in the development of artificial feeds (Glencross et al., 2002).

\subsection{Energy}

Although not a nutrient itself, energy is present and "stored" in the chemical bonds that hold the molecules in the nutrients together. The amount of energy in the various nutrients that make up a feed is of great importance as well as the capacity of different species to utilize the energy contained in the different nutrients. Fish, like most animals, eat to satisfy energy needs. Dietary nutrients should be balanced so that the fish will have enough of the essential nutrients for optimum growth when energy needs are satisfied. Energy acquired through the ingestion of food is used in metabolic processes, deposited as new body tissues (growth or energy gain, maturation) or lost as waste in faeces or excretion. Bioenergetics is concerned with the study of rates of energy intake and transformation within the organism, providing the 
physiological framework for the study of the relationships between feeding rates and growth rates, or maturation of fish subjected to different environmental conditions. It is generally believed that fish, like other animals, control their feed intake in order to meet their energy intakes in tune with their growth rates. Moreover, energy requirements can be affected by water temperature as well as by the growth stage and/or state of the fish, and these requirements can only be met by the digestible energy content of the diet. Furthermore, the digestible energy of each ingredient in the diet is crucial to promote adequate feeding and growth rates.

Tunas are pelagic fish with rather particular physiological features. They may or may not have a swim bladder to control buoyancy and hydrostatic equilibrium, but they do not possess a respiratory pump (lacking a functional operculum to move the water through the oral cavity and gill chamber), and so are ram ventilators and never stop swimming. Furthermore, they retain metabolic heat through the red muscle rete mirabilis (heat exchanger) and high respiratory rate, possibly independent of ambient water temperature and allometric growth. Therefore, thunniform swimming, the capacity to conserve metabolic heat in red muscle and other body regions (regional endothermy), an elevated metabolic rate and other physiological rate functions, and a frequency-modulated cardiac output, distinguish tunas from most other fishes. These specializations support continuous, relatively fast swimming by tunas and minimize thermal barriers to habitat exploitation, permitting niche expansion into high latitudes and to ocean depths previously regarded as beyond their range (Graham and Dickson, 2004).

The energetic requirements of tunas for maintenance, growth and maturation, and their capacity to utilize the energy contained in the food must be considered. The dietary energy requirement is highly related to their physiological requirement to thermoregulate, as the processes required to generate metabolic heat in an environment with a constant thermal 
gradient will place an enormous energetic demand on the fish (Carey et al., 1984). Little is known about the bioenergetics of NBT, but there have been some studies on skipjack (Katsuwonus pelamis), yellowfin tuna (YFT, Thunnus albacares) (Kitchell et al., 1978) and southern bluefin tuna (SBT, Thunnus maccoyii) (Davis, 1997). The results obtained by Kitchell et al. (1978) with $1 \mathrm{~kg}$ fish (K. pelamis) demonstrated that net energy budget and assimilation efficiencies are almost constant, irrespective of the ration given, although growth and production efficiencies decrease greatly as ration increases (Lucas, 1996). Based on nonparametric analysis from several moist and baitfish diets fed under various feeding regimes in trials with SBT, a response surface model was developed, suggesting that both protein and energy were key factors in the diet of SBT, but that dietary energy had a greater influence than dietary protein (Glencross et al., 1999a, b). Modelling of the nutritional value of feed with respect to the effects of dietary energy on feed conversion suggested that dietary fat levels were a key factor in influencing the energetic value of the diets for SBT (Glencross et al., 2002).

In fattening operations with caged SBT, the decline in diet intake throughout a production season and the slowing of growth may be a key indicator to estimate the levels of dietary intake required for maintenance. Under conditions where ambient water temperatures were less than $15^{\circ} \mathrm{C}$, and when growth had virtually ceased, an average of about $0.15 \mathrm{MJ}$ of gross energy (GE) was consumed per kg body weight per day. Based on these data for maintenance, the energetic requirement for $1 \mathrm{~kg}$ of gain $\left(\right.$ at $16^{\circ} \mathrm{C}$ ) was estimated to be around 56 MJ of GE (Glencross et al., 2002). This value is about twice that estimated for cultured Atlantic salmon, Salmo salar (NRC, 1993). In studies examining growth rates of SBT as a function of average protein intake, GE intakes as a function of growth have also been evaluated (Glencross et al., 2002). GE intakes were consistent with protein intake assessments, and a levelling off of growth was observed with a daily energy intake of about 
0.3 MJ per kilogram body weight per day (no compensation for variation in ambient water temperature was taken into account).

The energy needs of YFT broodstock were predicted based on oxygen and caloric requirements as functions of tuna size and water temperature, with fish increasing caloric intake with increasing size, resulting in caloric consumptions ranging from 9 to $104 \mathrm{kcal} \mathrm{kg}^{-1}$ day $^{-1}$ and from 125 to $1439 \mathrm{kcal} \mathrm{fish}^{-1}$ day $^{-1}\left(0.04-0.43 \mathrm{MJ} \mathrm{kg}^{-1} \mathrm{day}^{-1}\right.$ and from $0.52-6.02 \mathrm{MJ}$ $\mathrm{kg}^{-1}$ day $^{-1}$ ) (Wexler et al., 2003).. Recent studies at the University of Kinki in Japan with juvenile PBT have shown that starving fish of $0.85 \mathrm{~g}$ over 4 days induced severe damage and mortalities of over $90 \%$ (Takii et al., 2005). The same study also showed that the daily maintenance energy, protein and fat requirements of juveniles were $0.14 \mathrm{MJ} \mathrm{GE} \mathrm{kg}{ }^{-1}$ body weight, $5.46 \mathrm{~g} \mathrm{~kg}^{-1}$ body weight and $0.44 \mathrm{~g} \mathrm{~kg}^{-1}$ body weight, respectively. These results indicated that the low fasting tolerance of the juvenile tuna was related to their high energy and protein demands in comparison to other aquacultured fish.

Analysis of the standard metabolic rate (SMR) for tuna species showed there was a strong allometric relationship with body mass $\left(423 \mathrm{M}^{0.86}, \mathrm{R}^{2}=0.97\right)$, demonstrating that the inter-specific SMR scale with respect to body mass for tuna was similar to that of other active teleosts, but was around 4-fold higher (Fitzgibbon et al., 2008). However, routine metabolic rate (RMR), rather than SMR, is more appropriate in ram-ventilating species that are physiologically unable to achieve complete rest. Thus, respiration was measured in a large mesocosm respirometer deployed within a marine-farm sea cage for 29 days. Fasted fish were maintained within the respirometer up to $42 \mathrm{~h}$ while dissolved oxygen dropped by $0.056 \mathrm{mg}$ $\mathrm{l}^{-1} \mathrm{~h}^{-1}$. Mean mass-specific RMR in fasting SBT was measured at $460 \mathrm{mg} \mathrm{kg}^{-1} \mathrm{~h}^{-1}$ at a mean water temperature of $19{ }^{\circ} \mathrm{C}$. (Fitzgibbon et al., 2008). Fish rely upon lipids and proteins, primarily, as respiratory substrates and the appropriate oxycalorific coefficient for use in estimating energy metabolism in fish species has been suggested to be close to $13.59 \mathrm{~kJ}$ per 
gram of oxygen consumed (Jobling, 1994; Lucas, 1996). In this context, RMR in fasting SBT can be estimated as $0.15 \mathrm{MJ}$ per kg body mass per day. The effect of feeding on the rate of oxygen consumption $\left(M_{\mathrm{O} 2}\right)$ was also determined in SBT (Fitzgibbon et al., 2007). Both $M_{\mathrm{O} 2}$ and swimming velocity were elevated post feeding. The increased $M_{\mathrm{O} 2}$ was probably due to specific dynamic action (SDA), and the increased swimming velocity may be required to increase ventilation volume as a response to the enhanced metabolic demand associated with SDA. Peak post-prandial $M_{\mathrm{O} 2}$ increased linearly with ration size to a maximum $1290 \mathrm{mg} \mathrm{kg}^{-}$ ${ }^{1} \mathrm{~h}^{-1}\left(0.42 \mathrm{MJ} \mathrm{kg}^{-1} \mathrm{day}^{-1}\right)$, corresponding to 2.8 times the RMR. When converted to energy equivalents, the total magnitude of SDA was linearly correlated with ration size to a maximum of $192 \mathrm{~kJ} \mathrm{~kg}^{-1} \mathrm{~h}^{-1}\left(4.61 \mathrm{MJ} \mathrm{kg}^{-1}\right.$ day $\left.^{-1}\right)$ and, as a proportion of GE ingested (SDA coefficient), it averaged 35\%. Therefore, although the factorial increase of SDA in SBT was similar to that of other fish species, the absolute energetic cost of SDA was much higher. The ration that SBT require to equal the combined metabolic costs of SDA and RMR was estimated to be $3.5 \% M_{\mathrm{b}}$ of Australian sardines per day (Fitzgibbon et al., 2007).

A recent study has measured the oxygen consumption and metabolic rates of juvenile PBT and YFT swimming in a swim-tunnel respirometer at $20^{\circ} \mathrm{C}$ (Blank et al., 2007). $M_{\mathrm{O} 2}$ ranged from 235 to $498 \mathrm{mg} \mathrm{kg}^{-1} \mathrm{~h}^{-1}\left(0.08-0.16 \mathrm{MJ} \mathrm{kg}^{-1}\right.$ day $\left.{ }^{-1}\right)$ for PBT and from 164 to 405 $\mathrm{mg} \mathrm{kg}^{-1} \mathrm{~h}^{-1}\left(0.053-0.132 \mathrm{MJ} \mathrm{kg}^{-1}\right.$ day $\left.{ }^{-1}\right)$ for YFT, depending upon swimming speed. PBT had higher metabolic rates than YFT at all swimming speeds tested and, at a given speed, PBT swam with higher tail beat frequencies and shorter stride lengths than YFT. The higher $\mathrm{Mo}_{2}$ recorded in PBT was consistent with the elevated cardiac performance and enhanced capacity for excitation-contraction coupling in cardiac myocytes of these fish. Compared to tropical tuna, NBT and PBT are endothermic and have higher temperatures, heart rates, and cardiac outputs. The increased cardiovascular capacity to deliver oxygen in bluefin may be associated with the evolution of higher metabolic rates. These physiological traits may 
underlie thermal-niche expansion of BFT and PBT relative to tropical tuna species (Blank et al., 2007). The results and conclusions of this study may appear contradictory with those for energy requirement of YFT broodstock (Wexler et al. 2003) when data are recalculated in homologous units ( $\left.\mathrm{MJ} \mathrm{kg}{ }^{-1} \mathrm{day}^{-1}\right)$, and less clear differences in terms of energetic requirements can be distinguished between "tropical tunas" and "endothermic tunas", or tuna species not habiting tropical and sub-tropical waters. Both groups share a common pelagic lifestyle but, while tropical tunas have several annual reproductive cycles, non tropical tunas have only one reproductive migration and spawning season per year and site fidelity spawning grounds, denoting different life cycle strategies and, in consequence, different energetic demands and energy allocations within the yearly or seasonal cycle.

\subsection{Protein and amino acids}

Dietary protein serves two main purposes in fish; firstly, as a source of amino acids required for the synthesis of new proteins for growth, reproduction and replacement of existing protein in the process of turnover; and secondly, protein excess to the above requirements will be utilized for energy. The dietary protein to energy balance, the amino acid composition and digestibility of the dietary protein(s), and the amount of non-protein energy sources in the diet all influence the optimal dietary protein level for fish. Dietary protein requirements can be broken down into three main categories, gross protein requirements and qualitative and quantitative amino acid requirements, and some general assumptions can be made based upon existing knowledge of other species. The estimated gross protein requirements of fish vary from around $30 \%$ to about $55 \%$ of the diet. The lower protein requirements are usually associated with warm freshwater species that can also utilize carbohydrate to a greater extent than most other fish. As marine fish and also top predators, the large tuna species are likely to 
be towards the high end of this range and it is probable that their gross protein requirement will not be below $40 \%$. Stage of development and size of fish are likely to affect the gross protein requirement as, generally, it decreases with both age and size (Wilson, 2002). Water temperature is another factor that could affect the protein requirement.

Determining the qualitative requirements for amino acids is a tedious and timeconsuming process, but it has been carried out for many species. The same 10 amino acids (namely arginine, histidine, isoleucine, leucine, lysine, methionine, phenylalanine, threonine, tryptophan and valine) that have been shown to be essential for most animals have also been found to be required by all the finfish studied to date (Wilson, 2002). Therefore, it is most likely that the same amino acids will also be required by tunas. The quantitative requirements for all these amino acids have been determined in several species and so can be estimated for tunas using the values obtained for other carnivorous marine fish such as gilthead sea bream (Sparus aurata), Atlantic salmon or yellowtail (Seriola quiqueradiata). However, with diets utilizing fishmeal and/or squid meal as the sole protein source these requirements should be fully met, but particular attention to the essential amino acids will be required if diets utilizing other sources of proteins are used (see section 6.2).

No specific studies on protein utilization by tunas have been conducted to date, but several alternative and/or indirect methods of measuring protein utilization and amino acid requirements have been examined in SBT. Studies with SBT have examined growth rates as a function of protein intake, taking into consideration the effect of water temperature and dietary energy, and results obtained suggest that optimal daily protein intake for growth is about 10 g protein $\mathrm{kg}^{-1}$ day $^{-1}$ (Glencross et al., 1999a, b, 2002), while Takii et al. (2005) determined the daily protein requirement for maintenance in PBT to be $5.46 \mathrm{~g}$ per $\mathrm{kg}$ body weight. An indicator of protein metabolism is the measurement of the capacity for protein synthesis, and a value of $8 \mathrm{mg}$ RNA g protein $^{-1}$ was estimated for maintenance in SBT (Carter 
et al., 1998). This value is about four times higher than that estimated for other fish of equivalent weight, culture temperature and feed intake (Houlihan et al., 1995; Glencross et al., 2002), and similar to that of an unfed mammal (Glencross et al., 2002). As a consequence, the significantly higher energy demand associated with protein turnover, even at zero growth, may suggest a closer relationship between protein metabolism and energy requirements in SBT than in other fish (Glencross et al., 2002). The requirements for essential amino acids in SBT have been estimated based on the amino acid composition of both red and white muscle, and an ideal dietary amino acid balance has been proposed (van Barneveld et al., 1997). As with other fish species, lysine has been estimated as the key limiting amino acid and, in consequence, diets have been generally formulated to account for this limitation (Glencross et al., 2002).

\subsection{Lipids and fatty acids}

In fish, an excess of energy, whether derived from protein, carbohydrate or lipid, is stored as triacylglycerol (TAG) within the adipose tissue (cells) of the body. Adipose cells in fish are found beneath the skin, between muscle myotomes and around the abdominal (visceral) organs and the membranes that support the organs. However, liver also acts as a fat storage organ in some fish, generally non-migrating species that have poorly developed red muscle. In contrast, migrating and pelagic lifestyle fish species develop an important mass of richly vascularised red muscle and preferentially store lipids under the skin, and in the muscle and abdominal cavity. They also have a higher average fat content and greater variation in fat content than those which do not migrate, indicating that fat is a major energy source during migration. Dietary lipids are likely to play a particularly important role in the nutrition of tunas because of their high energy requirement described above. The large percentage of body 
weight that is muscle tissue allows a large amount of energy to be stored in tuna if depot fats are laid down in both red and white muscle. Fat deposition in tuna muscle types is unevenly distributed, with dorsal muscle (akami) leaner than ventral muscles that are fattier (otoro, wakaremi). This is a significant source of energy that may be used for movements between areas of food abundance in a habitat where such areas can be widely separated.

Dietary lipids perform four main functions in the body: (i) provide energy, (ii) provide essential fatty acids (EFA), (iii) serve as structural components and, (iv) serve in regulatory functions (eicosanoids, second messengers, etc.). As with protein, lipid requirements can be broken down into three main categories, gross lipid requirement, and qualitative and quantitative EFA requirements. Virtually nothing is known about any of these requirements for tunas, but again some general assumptions can be made based on existing knowledge of other species.

Certainly a major consideration in the diet of tunas will be the gross lipid level of the diet. Research will be required to identify the ideal lipid levels at different life stages of the fish, particularly in relation to season and final grow out to ensure optimal growth without compromising quality. Therefore, the dietary protein sparing effect of lipids, which allows protein to be used optimally for growth without depositing excess lipid in the flesh, has to be examined in tunas. It has been concluded that, in general, fish diets containing between 10 to $20 \%$ lipid gave optimal protein utilization and growth rates while minimising undesirable alterations in carcass composition (Cowey and Sargent, 1979). Considering the feed fish used in previous grow out trials with NBT and SBT (see below) generally have lipid contents in this range, this appears a good starting point for tunas. It has been observed that there is a direct relationship between the dietary lipid content and the food conversion ratio (FCR) on a dry matter basis in SBT (Glencross et al., 1999a). In consequence, the nutritional performance of the feed can be improved by increasing the dietary lipid content (Glencross et al., 1999b). 
The farmed tuna market will undoubtedly include export to Japan for the very high value products, sushi and sashimi, where flesh quality is paramount and highly prized, with high quality fish realising four times the price of lower quality fish. Fat (lipid) content of the flesh is a key factor determining flesh quality in tuna, and so lipid content of the diet and feeding regimes will be an area of nutrition requiring close attention.

Another vital area in lipid nutrition is the provision of sufficient amounts of the correct EFA. The EFA requirement of fish varies both in qualitative and quantitative terms. In freshwater fish, including salmonids such as rainbow trout (Oncorhynchus mykiss) and Atlantic salmon, the EFA requirements can be met by the shorter chain PUFA, $\alpha$-linolenic (LNA; 18:3n-3) and/or linoleic (LOA; 18:2n-6) acids (Sargent et al., 2002). LNA and LOA are converted to lc-PUFA through a series of alternating desaturations and chain elongations mediated by microsomal fatty acid desaturation and elongation systems (Tocher, 2003). Freshwater fish, including salmonids, possess the $\Delta 6$ and $\Delta 5$ fatty acyl desaturases and PUFA elongases required for the production of EPA and DHA from LNA, and arachidonic acid (ARA; 20:4n-6) from LOA (Tocher, 2003). In contrast, all marine fish studied to date have only very limited ability to produce the biologically active lc-PUFA from LNA and LOA and so have an absolute dietary requirement for the preformed lc-PUFA (Tocher, 2003). As described earlier, the fatty acid profile of lipids from flesh of wild-caught tunas show high levels of DHA, possibly suggesting that tunas may have a high requirement for this fatty acid (Nichols et al., 1998). The relatively high level of DHA in tuna and the high DHA:EPA ratio may have consequences regarding the formulation of artificial diets as the DHA:EPA ratio seldom exceeds 2 in most commercially available fish oils used in feed formulations (Ackman, 1980). Furthermore, marine fish may also have a limited capacity for the conversion of EPA to DHA (Sargent et al., 1993, 1995). Although the lipid biochemistry underpinning the high level of DHA and the high DHA:EPA ratio in tuna is unclear, it has 
been generally assumed that tuna must selectively accumulate and retain DHA in their tissues (Ishihara and Saito, 1996; Saito et al., 1996). Biochemical and molecular studies focussing on the lc-PUFA biosynthetic pathway in addition to nutritional trials are required to fully elucidate this area. In the first instance, it appears that it would be advisable that the oil used in experimental formulated diets is a high quality marine fish oil, containing high total n-3 lcPUFA and with as high a DHA:EPA ratio as possible.

\subsection{Carbohydrate}

The capacity of most fish to effectively utilize dietary carbohydrate for energy is limited, particularly in the case of marine fish (Cowey, 1988). Marine, carnivorous fish are unable to use dietary carbohydrates to the same extent that omnivorous fish do, related to the lower expression/activities of amylases, carbohydrate metabolism enzymes and poorer insulin response. The digestive physiology of tunas suggests that dietary carbohydrate may not be well utilized, as carbohydrate metabolising enzymes in the gut may be absent or very low. For instance, the study and characterization of digestive enzyme capabilities of SBT identified residual $\alpha$-amylase activity, though not enough to be considered as viable for large-scale carbohydrate digestion (Van Barneveld et al., 1997). However, higher levels of $\alpha$-amylase

activity were reported in intestinal tissues from PBT (Matus de la Parra et al., 2007). Therefore, it is not clear whether carbohydrate will feature in the diets of tunas in a nutritional capacity, although starch has been used as a filler/binder in some experimental diets for SBT (Glencross et al., 2002).

\subsection{Vitamins and minerals}


Tunas will likely require the same range of water-soluble and fat-soluble vitamins that have been identified as being required in the diets of all fish studied to date (van Barneveld et al., 1997; Halver, 2002). The quantitative requirements for each vitamin varies between species and so theoretically will have to be determined in tunas. Moreover, vitamin deficiency signs in tunas may be similar to those reported for other fish species but the onset of deficiency might be induced more rapidly by the fast metabolic rate and fast-growing nature of tunids. However, a generalised vitamin premix for marine fish is an appropriate starting point for initial trials and may be sufficient to satisfy tuna requirements and prevent any vitamin deficiency symptoms. One possible aspect of a putative experimental diet that may have consequences regarding vitamin requirements for tunas is the high level of n-3 lc-PUFA and the high DHA:EPA ratio that may be required. Particular care should therefore be taken with the level of the vitamins that possess antioxidant functions, especially vitamins $\mathrm{E}$ (tocopherol) and $\mathrm{C}$ (ascorbate). Furthermore, high doses of these two vitamins may also improve disease resistance in tunas, as has been demonstrated in yellowtail (Masumoto, 2002). Vitamin A, a morphogenetic nutrient, includes vitamers that possess biological activity playing key roles in morphogenesis, cellular differentiation and proliferation processes. Thus, since fish are incapable of vitamin A synthesis, deficiency or dietary excess of this lipid soluble nutrient might result in abnormal growth and development (Fernandez et al., 2008). The possibility that intact phospholipids, particularly phosphatidylcholine and phosphatidylinositol, in addition to the vitamins choline and inositol, may also have a growth promoting effect in diets for larval tuna as they have in other marine fish species is an aspect that will require study at some point. A mixed vitamin formulation supplied at a level of $0.5-1.5 \%$ of the weight of the feed plus $500 \mathrm{mg}$ vitamin $\mathrm{C}$ fish ${ }^{-1}$ day $^{-1}$ were used to feed YFT broodstock in captivity (Wexler et al., 2003). Moreover, practical evidence with SBT suggests that enriching and/or fortifying with a vitamin premix is particularly important when using a poorer quality whole 
fish feed (not fresh and/or rancid) and/or when the fish are in poor condition. Use of vitamin premixes increases the levels of $\alpha$-tocopherol in fish tissues, mainly in flesh (Glencross et al., 2002).

Particular attention should also be paid to the mineral mix in the diets for tunas, since deficiency signs could also appear quickly, for the same reasons as above, in response to a lack or low levels of particular minerals. Although tunas can absorb many minerals by drinking sea water, essential critical minerals that may require to be supplemented to the diet in adequate amounts include iron, phosphorus, calcium and magnesium, as shown for another pelagic carnivorous fish, the yellowtail (Masumoto, 2002).

\subsection{Characterization of the digestive enzymes and digestibility}

Digestion is a complex process involving enzyme and fluid secretions and motility, which results in absorption and evacuation. As alluded to above, examination of digestive enzyme capacities of tuna may give clues relevant to nutrition. For instance, it may facilitate the development of artificial gastrointestinal models (such as everted intestine) where food or feed can be digested with the tuna's own enzymes, providing data useful for the formulation of novel diets. SBT digesta enzymes have provided useful data in in vitro digestibility assays of key feed ingredients (Houlihan et al., 1995). Moreover, in vitro assessment techniques and surrogate methodologies have also been developed for the study of digestibility of key feed ingredients by SBT digesta enzymes (Carter et al., 1998; Carter et al., 1999; Brandsen et al., 1999; Glencross et al., 2002). Therefore, considering that elements such as nitrogen (by product of protein metabolism), and particularly phosphorus, make up the organic wastes capable of causing environmental impact in tuna farming operations, the digestibility of total nitrogen and total phosphorus was determined in vivo in NBT during cage intensive fattening 
(Aguado et al., 2004). Tunas were fed ad libitum once a day with a mixture of mackerel, herring, pilchard and gilt-sardine. Body weight of sampled tuna ranged between 150 and 350 $\mathrm{kg}$. Faeces were collected by dissection of the distal intestine after slaughtering, and directly with a manual sieve by scuba divers in the sea cages. Endogenous inert marker was acid insoluble ash. Apparent digestibility coefficient (ADC) for total nitrogen was lower when faeces were collected by dissection of the intestine (DI: $658.2 \mathrm{~g} \mathrm{~kg}^{-1}$ ) than when by direct collection (DC: $937.4 \mathrm{~g} \mathrm{~kg}^{-1}$ ). Total phosphorous ADC was lower when faeces were directly collected (DC: $481.4 \mathrm{~g} \mathrm{~kg}^{-1}$ ) than when collected by intestine dissection (DI: $661.9 \mathrm{~g} \mathrm{~kg}^{-1}$ ). The nitrogen digestibility in tuna was as high as in other carnivorous fish, while low phosphorous digestibility, as in many fishes, could be related to excess phosphorous in the diet. The results for directly collected faeces appeared to be more consistent and appropriate for waste output estimation. Results demonstrated the need for a more accurate nutritional evaluation, and development of formulated artificial diets (Aguado et al., 2004).

The digestive enzyme activities in extracts of stomach, caecal mass, and proximal, middle and distal intestine of PBT have been evaluated for specific activity and characterized for $\mathrm{pH}$ and temperature optima (Matus de la Parra et al., 2008). Most proteolytic and lipolytic activities were maximal in the alkaline range, peaking at $\mathrm{pH} 9.0$, and at temperatures between 35 and $60^{\circ} \mathrm{C}$. However, pepsin showed maximal activity in the acid range (pH 3.0). Three pepsinogens and the corresponding pepsins from the gastric mucosa of PBT were purified and characterized and the complete amino acid sequence determined (Tanji et al., 1988; 1996; 2009). A higher level of alkaline proteolytic activity was detected in the caecal mass than in the proximal intestine. Lipolysis appeared to be due to a non-bile salt dependent lipase, as activity was significantly reduced in the presence of bile salts (Matus de la Parra et al., 2008). Although not involved in intestinal digestion, phospholipase $A_{1}$ activity of crude enzyme extracts from ovaries of several scombrid fish was studied and characterized (Hiratsuka et al., 
2008). The optimum $\mathrm{pH}$ and temperature for the phospholipase $\mathrm{A}_{1}$ activity of the crude enzyme from ovaries were in the range of $\mathrm{pH} 6-7$ and $20-30^{\circ} \mathrm{C}$, respectively, and calcium ions were not required. As a substrate, phosphatidylcholine was more easily hydrolyzed than phosphatidylethanolamine by this enzyme as were diacyl phospholipids compared to plasmalogen phospholipids (Hiratsuka et al., 2008).

Little is known about hormonal regulation of the gastrointestinal tract in tunas, but the few data available for other teleosts suggest that the regulatory pathways and molecules are relatively conserved among vertebrates, although some specific responses in fish may differ from mammals (Buddington and Krogdahl, 2004). Gastrointestinal hormones such as, ghrelin, peptide $\mathrm{YY}$ and cholesystokinin (CCK), not only regulate digestion, but may also act as appetite/satiety modulating signals in the brain (Volkoff et al., 2005; Rønnestad et al., 2007).

\subsection{Gustatory response}

Certain chemical components of feeds are known to act as gustatory stimulants or palatability enhancers. The most common chemicals identified as feeding stimulants are amino acids, betaine, quaternary ammonium bases, and nucleotides (e.g. IMP, inosine monophosphate) (Rust, 2002). Neural gustatory responses of PBT to compounds extracted from prey organisms were studied by electrophysiological recording from the facial nerve supplying the anterior palate (Kohbara et al., 2006). Of the 17 amino acids tested, L-proline was the most potent, followed by L-leucine, L-methionine, L-alanine, L-valine and L-isoleucine. Among the 7 nucleotide-related substances tested, uridine-5'-monophosphate (UMP), inosine5 'monophosphate (IMP) and adenosine-5'-monophosphate (ADP) were highly stimulatory. Betaine was highly stimulatory, but trimethylamine oxide and ammonium chloride were 
ineffective, and lactic and pyruvic acids were only effective at higher concentrations (Kohbara et al., 2006).

\section{NUTRITION AT CRITICAL STAGES OF ONTOGENY}

\subsection{Broodstock nutrition}

Feed and feeding preferences in tunas are related to physiological condition, including maturation (Fushimi et al., 1996). In Japan, the broodstock diet for PBT has been based on species of local baitfish and included $51 \%$ mackerel (Scomber spp.), $30 \%$ jack mackerel (Trachurus japonicus), $10 \%$ squids (Decapterus tabl, Todarodes pacificus) and $3 \%$ sardines (Sardinops melanosticus) (Sawada et al., 2005). Similarly in Panama, YFT broodstock are fed on local baitfish and squids including Pacific anchoveta (Cetengraulis mysticetus), bigscale anchovy (Anchovia macrolepidota), market squid (Loligo opalescens), and Argentine shortfin squid (Illex argentinus) (Wexler et al., 2003). The daily rations for YFT broodstock ranged from $1 \%$ to $10 \%$ body weight day ${ }^{-1}$ and showed FCRs that varied from 10.9 to 34.6 on a wet weight basis, with an average of 18.2. These values were comparable to FCRs obtained with similar sized SBT fed pilchards (Smart, 1996).

There are a number of aspects of fish reproduction that may be affected by nutritional status: the time to first maturity, the number of eggs produced (fecundity), egg size and egg quality as measured by chemical composition, hatchability and larval survival. Energy is partitioned by fish between the various physiological processes involved in maintenance, growth and reproduction. Thus, maintenance requirements are met first and then excess energy divided between growth and reproduction, with the relative partitioning between the latter two varying between species and strains of individual species. There are few studies 
investigating reproductive effort and nutrient requirements of fish for gonad development and reproductive success, but those that have been undertaken indicate great species variability (Izquierdo et al., 2001; Watanabe and Vasallo-Agius, 2003). Most work has focussed on EFA and fat-soluble vitamin and pigment requirements, and it has been generally assumed that the amino acid requirements of broodstock are similar to those for optimal growth (Izquierdo et al., 2001; Watanabe and Vasallo-Agius, 2003). We are still far from developing adequate artificial diets for tunas and even further for tuna broodstock. However, an appropriate tuna broodstock diet must satisfy all the requirements for high fecundity as well as egg and sperm quality for optimum spawning performance and fertilization. There must be an optimal protein level for reproductive success in tunas, and so dietary protein will also have to be carefully evaluated for effects on reproduction in fish used as broodstock. It is likely that high quality protein sources such as fishmeal and/or squid meal would be desirable ingredients as well as high quality fish oils possibly including tuna orbital oil and/or leicithin from bonito oil in order to supply adequate amounts of essential amino acids, EFAs and phosphoglycerides in suitable proportions. All these ingredients have been shown to improve egg quality in several marine species. The n-3 lc-PUFA are essential for egg quality together with lipid soluble compounds such as carotenoid pigments (astaxanthin, capsanthin and capsorbin) and tocopherols. The inclusion of carotenoids and vitamin $\mathrm{E}$ in broodstock diets for pelagic marine carnivorous fish, such as yellowtail and striped jack (Pseudocaranx dentex) has resulted in superior gonadal development and spawning performance, apparently due to the radical quenching abilities of these compounds (Watanabe and Vasallo-Agius, 2003). In general, there is an urgent need for further research in this area for fast-growing marine pelagic fish, but particularly for tunas.

\subsection{Larval nutrition}


Like many other pelagic marine fish, the early life stages of tuna are visual predators feeding during daylight hours (Uotani et al., 1990; Young and Davis, 1990), with larvae consuming primarily small zooplankton, mainly copepods and copepoda nauplii (Uotani et al., 1990). At a very early developmental stage, tuna larvae acquire predatory piscivorous habits and consume daily rations between 25 and 50\% of total body mass (Young and Davis, 1990; Tanabe, 2001). Cannibalism is usually found in the larvae and juveniles of tuna in nature, mainly in reproductive areas (Tanabe, 2001). There are few studies of wild larval tuna. However, in order to assess the nutritional status of field-caught larval PBT, starvation experiments of hatchery-reared larvae were conducted and changes in the RNA/DNA ratio of fed and starved larvae analyzed (Tanaka et al., 2008). The poor survival rate of PBT larvae and immediate growth retardation suggested that PBT larvae have a very low tolerance to starvation. The RNA/DNA ratios of fed larvae were approximately $2-4$, whereas it was $1-3$ in starved larvae. The nutritional status of field-caught tuna larvae collected in the north western Pacific Ocean was negatively correlated to the ambient prey densities. This study suggested that the nutritional condition of larval PBT was influenced by the ambient prey density, and starvation itself and starvation-induced predation could contribute to mortality during the larval period of PBT (Tanaka et al., 2008).

\subsubsection{First feeding technology}

As with all marine fish, first feeds for larval tuna will, for the time being, be largely dependent upon live feeds (Lee, 2003). Larvae rearing technologies for PBT and YFT have been mainly developed in Japan and Panama, respectively. Larval rearing tanks for PBT are supplied with filtered and UV-irradiated sea water at $25^{\circ} \mathrm{C}$; the rearing water is not changed 
until day 2 after hatch and then the water exchange is increased gradually up to 3-5 exchanges per day. The newly hatched larvae, stocked in 50001 tanks at a density of about 6 larvae $1^{-1}$, commenced feeding on day 3 with DHA-enriched rotifers Brachionus rotundiformis and B. plicatilis to 25 days after hatching (DAH) (Sawada et al., 2005; Masuma et al., 2008). Artemia nauplii were fed from 10 to about $25 \mathrm{DAH}$, and fish larvae of species such as Pagrus major, Lethrinus nebulosus, Plectropomus leopardus or Oplegnathus fasciatus were introduced from 12 to 30 DAH. Minced fish was fed from 15-30 DAH onwards when fish were about $30 \mathrm{~mm}$ in total body length (Fushimi et al., 1996; Lee, 2003). YFT larvae were cultured in 10001 tanks supplied with filtered and UV-sterilised seawater at an average temperature of $26^{\circ} \mathrm{C}$ from 0 to $30 \mathrm{DAH}$ at an initial stocking density of 40 larvae $1^{-1}$ (Kaji, 2002). The microalgae Nannochloropsis oculata was added to the rearing tanks from 4 to 31

DAH. Larvae were fed on rotifers from 4 to $30 \mathrm{DAH}$, Artemia nauplii and fish larvae (Lethrinus nebulosus and L. miniatus) from 15 to $30 \mathrm{DAH}$, and then frozen fish and minced fish meat as development and growth continued (Kaji, 2002).

The use of mixed live feeds as above may lead to complex prey-predator interactions among planktonic organisms in larval tanks. This was studied in tanks of larval PBT and two different carbon pathways were revealed by carbon flow models constructed from the results of feeding experiments (Nakagawa et al., 2007). One pathway was from autotrophic nanoplankton to rotifers to fish larvae (artificial food chain) and the other was from bacteria to heterotrophic nano-plankton to heterotrophic micro-plankton (a microbial loop). PBT selectively consumed heterotrophic micro-plankton, especially dinoflagellates, throughout the experiment, and the microbial loop was linked to the artificial food chain. Therefore, this study suggested that a microbial loop, established naturally, contributes energy and nutrient gain to PBT larvae reared in an artificially controlled environment (Nakagawa et al., 2007). 


\subsubsection{Embryogenesis and yolk sac stage larvae}

The analysis of the variations of energy and nutrient contents during embryogenesis and yolksac larvae period can give useful information of the nutritional requirements during early larval stages (Sargent et al., 2002). The types of nutrients used for energy and embryonic development are species-specific and closely correlated to nutrient requirements during the postlarval and juvenile stages (Rønnestad and Fyhn, 1993). However, there are few studies on nutrient utilisation during embryonic development in tunas (Takii et al., 1997). Fertilized PBT eggs were incubated until hatching at $27^{\circ} \mathrm{C}$ and changes in egg moisture, total nitrogen and total phospholipids were determined (Takii et al., 1997). Egg protein gradually increased, and free amino acid decreased, with development. TAG, a main egg constituent (42\% of egg dry matter), and gross energy both decreased from early cleavage to just before hatching (Takii et al., 1997). The rapid TAG decrease during embryonic development may suggest a high lipid requirement for PBT at post-larval and juvenile stages to support rapid growth.

\subsubsection{Early digestive capabilities}

Activities of aspartate aminotransferase, alanine aminotransferase, creatine kinase and lactate dehydrogenase in developing PBT fell between the stages of early cleavage and Kupffer's vesicle and rose thereafter. Alkaline phosphatase remained high until embryo formation and fell rapidly thereafter (Takii et al., 1997). These increasing enzyme activities, with the exception of alkaline phosphatase, denote organ differentiation and formation immediately before or after Kupffer's vesicle in PBT eggs (Takii et al., 1997). Most marine fish larvae have poorly developed digestive systems at first feeding (Sargent et al., 2002), although the larval type-gut has a considerable processing capacity that can support high growth rates, and 
the adult-type of digestive system (including a functional acid-producing stomach) only develops at metamorphosis, weeks to months after first feeding. However, several studies have revealed that in scombrid larvae such as Spanish mackerel (Scomberomerus niphonius), chub mackerel (Scomber japonicus) and striped bonito (Sarda orientalis), and also NBT and YFT, the adult-type digestive system is established at the mid phase of the larval period or around the first feeding stage, during scombriform-type metamorphosis (Kaji et al., 1996; Miyashita et al., 1998; Kaji et al., 1999; Kaji, 2002; Kaji et al., 2002). Moreover, and in contrast to straight gut teleost fish larvae, bluefin tuna present a rotated gut, which permits retention of ingested food for some time in the anterior midgut, and retrograde peristalsis as a mechanism for filling the pyloric caeca (Rønnestad et al., 2007). This precocious timing of digestive system differentiation in scombrids may suggest an adaptation allowing the early appearance of piscivorous habits and high growth rates during the early life stages. Changing the feeding schedule from invertebrate zooplankton to fish larvae (see section 4.2.1) is therefore associated with the functional development of the digestive system and seems to be reasonably effective in the rearing of Thunnus larvae (Kaji et al., 1999). These studies on the development of digestive capacity of larval and juvenile tunas have shown that, after commencing feeding, trypsin-like and amylase-like activities increased as larvae grew, and pepsin-like activity increased and stomach and pyloric caeca functions developed from the post-flexion phase to juvenile transition (Miyashita et al., 1998; Kaji, 2002). The development of the tuna digestive system up to pre-flexion phase is mainly qualitative, but from the flexion and post-flexion phases development is both qualitative and quantitative. Thus, proteolytic capability subsequently increased during the postflexion phase, enabling a shift in food habits to piscivory (Kaji, 2002). This pattern of digestive system development might contribute to the rapid growth in the juvenile stage (Miyashita et al., 1998; Kaji, 2002). 
As indicated above, some morpho-histological studies describing the development of the digestive organs and the expression and activity of digestive enzymes has been undertaken regarding tuna larvae, but very little is known about the control systems of larval digestive physiology. $\mathrm{CCK}$ is an important hormone in higher vertebrates and plays a key role in the stimulation of pancreatic enzyme secretion, gallbladder contraction, intestinal peristalsis, delaying of gastric emptying and control of food intake. CCK producing cells release CCK into the blood vessels following chemical stimulation from ingested food. The location and timing of the appearance of CCK-producing cells in the gut of bluefin tuna larvae was examined and compared to other marine teleost larvae species. Entero-endocrine CCKproducing cells in rotated gut of bluefin tuna larvae were detected in the anterior part of the midgut (adjacent to pyloric caeca) in later stages, whereas in marine straight gut larvae, the cells appeared from hatching and were widely distributed all over the midgut (Rønnestad et al., 2007). Moreover, in very early stages neural CCK is quantitatively the dominant form and is progressively substituted by gut produced CCK as development proceeds (Rønnestad et al., 2007).

Aspects such as the environmental effects, feeding behaviour, digestive capacity during ontogeny, consumption and assimilation rates, and nutritional requirements from first feeding larvae to metamorphosis require to be investigated to provide a better basis for the formulation of larval specific diets and reliable larviculture of tunas.

\subsubsection{Live feeds and enrichment treatments}

The most commonly used live feeds for marine fish larvae, such as rotifers and Artemia nauplii, are primarily chosen for their ease of culture and use, rather than for any nutritional advantage (Sargent et al., 2002). Indeed, Artemia and rotifers are nutritionally unsuitable for 
marine fish larvae as they normally lack sufficient EFA contents, specifically the lc-PUFA, EPA and DHA (Sargent et al., 2002). Hence, the necessity for live feeds to be enriched in these nutrients prior to feeding to marine fish larvae. Larval nutrition of marine fish, specifically live feeds and their enrichment in EFA, has been an area of considerable research over the last few years and is not without technical difficulties (Conceição et al., 2007).

A primary focus has been determining the correct amounts and ratios of EPA, DHA and ARA, and these can vary greatly with species (Sargent et al., 2002; Tocher, 2003; Izquierdo, 2005). As described above, tuna species have generally higher levels of DHA and DHA:EPA ratios than in most other fish species and so it will be important to determine if this is reflected in a higher DHA requirement, particularly during larval development when there is considerable demand for lc-PUFA for neural tissue development (Sargent et al., 2002; Tocher, 2003; Mourente, 2003). The importance of DHA for the proper development of neural tissues has been demonstrated in larval Atlantic herring (Mourente and Tocher, 1992a; Bell et al., 1995; Mourente, 2003), European sea bass (Dicentrarchus labrax) (Navarro et al., 1997), gilthead sea bream (Mourente and Tocher, 1993; Mourente, 2003), and turbot (Psetta maximus) (Mourente et al., 1991; Mourente and Tocher 1992b; Mourente, 2003). Dietary deficiency of DHA resulted in larval herring having an impaired ability to capture prey at natural light intensities (Bell et al., 1995), delayed response to visual stimuli in larval sea bream (Benitez-Santana et al., 2007), and impaired schooling behaviour in yellowtail (Masuda et al., 1998; Ishizaki et al., 2001) and Pacific threadfin (Polydactylus sexfilis) (Masuda et al., 2001). A previously reported problem associated with NBT culture is mortality caused by trauma as a result of collision with the tank or net walls (Miyashita et al., 2000). The precise cause of these collisions is not known, but it is interesting to speculate that it could be related to neural development and larval nutrition. These studies imply a critical role for DHA in the functioning of neural tissue (brain and eye) in fish and also demonstrate 
the importance of dietary DHA in marine fish. Therefore, the delivery of sufficient DHA to developing marine fish larvae is of major importance and is not without problems (Sargent et al., 2002).

Very recently, the availability of larvae has enabled some studies comparing live feed enrichments to be carried out in PBT. The suitability of Artemia enriched with DHA and choline on the growth and survival rate of larvae was investigated (Biswas et al., 2006). Enrichment significantly increased the DHA levels in the Artemia, but the levels were still significantly lower than the reference diet, larvae of striped knifejaw (Oplegnathus fasciatus). Similarly, although growth and survival rates were significantly improved by both DHA enrichment and choline, the improvement was negligible compared with the higher growth and survival rate of the PBT fed the fish larvae (Biswas et al., 2006). As the growth failure was, at least partly, attributed to dietary DHA deficiency, further studies investigated the effect of graded DHA content in Artemia on the growth of PBT larvae (Seoka et al., 2007). The DHA contents in Artemia enriched with graded levels of DHA ethyl ester increased from $0 \mathrm{mg} \cdot \mathrm{g}^{-1}$ dry weight basis to $25 \mathrm{mg} \cdot \mathrm{g}^{-1}$, while the content in the reference diet, yolk-sac larvae of $O$. fasciatus, was $21 \mathrm{mg} \cdot \mathrm{g}^{-1}$. Although enriched Artemia significantly improved the growth of PBT larvae, it was negligible compared with the growth of the PBT larvae fed the $O$. fasciatus larvae (Seoka et al., 2007). This showed that the absolute level of DHA was not the only factor in growth promotion and that lc-PUFA ratios and/or the lipid source of the DHA is also important. Thus, the presentation of dietary DHA incorporated in phospholipids, as in the O. fasciatus larvae, may be desirable for the normal growth of PBT larvae, as suggested previously (Sargent et al., 2002; Tocher, 2003). To test this hypothesis two experiments were conducted to evaluate the effect of dietary phospholipid rich in DHA on growth and survival of PBT larvae and juveniles (Seoka et al., 2008). Diets were prepared from polar (phospholipid-rich) and neutral lipid fractions of salmon (Oncorhynchus gorbuscha) roe lipid 
and compared with enriched Artemia and fish (O. fasciatus) larvae. The growth and survival of PBT larvae and juveniles fed the high polar lipid fraction were significantly improved when compared with larvae fed neutral lipids or Artemia although for larvae the best growth and survival were obtained with the diet of $O$. fasciatus larvae (Seoka et al., 2008). Fish fed polar lipids or $O$. fasciatus larvae had higher total lipid contents, TAG levels, n-3 lc-PUFA and DHA levels, when compared with fish fed neutral lipids or Artemia. Interestingly, in juveniles, over $90 \%$ of deaths were caused by collisions with the tank walls and the significant difference in mortality between treatments implied that diet also affected behaviour (Seoka et al., 2008).

Particular attention should also be paid to enrichment of live preys, during early feeding, with antioxidant vitamins (E and $\mathrm{C}$ ) and lipid soluble morphogenetic vitamin $\mathrm{A}$. Most skeletal deformities appear during the larval stages in various marine fish, when many biological processes take place for organogenesis and morphogenesis. In particular, the dietary supply of vitamin A at first feeding can be critical for normal skeletogenesis, growth and development, although the precise dose is species specific and should be determined (Fernandez et al., 2008). Recent data on the biochemical composition of copepod species (total lipid, lipid class composition, total lipid fatty acid composition, total protein, free amino acids, protein-bound amino acids, pigments and vitamins) may prove an important base for the improvement of live feed enrichment emulsions or formulated feeds to be used during larval and early juvenile stages of tunids and/or other marine fish species culture (van der Meeren et al., 2008).

\section{CURRENT FEEDS}

\subsection{Whole fish}


There is limited information about feeding strategies, feed conversion ratios (FCR) and feed technology, and most data are related to fattening operations based on captured tuna. The fattening period varies between 3 and 10 months and tuna are usually fed baitfish on a basis of six days a week, twice a day. FCRs vary with the fattening season and temperature, 10:1 with high temperatures and 17:1 with low temperatures, and size of the fish, with smaller size tuna presenting lower FCRs than larger fish (O'Sullivan, 1993). Although there have been a number of attempts at NBT and PBT culture including both complete aquaculture and grow out/fattening programmes, there are few nutritional data pertaining to those studies (Buchanan, 1977; Vincent, 1981; Aitken, 1984; Okamoto et al., 1984; Belle, 1994; Doumenge, 1996). Wild-caught juvenile PBT were initially fed sand lance Ammodytes personatus, followed by anchovy Engraulis japonicus, sardine Sardinops melanosticus, jack mackerel Trachurus japonicus, mackerel scad Decapterus tabl, chub mackerel, spotted chub mackerel S. australasicus and Japanese common squid Todarodes pacificus (Sawada et al., 2005). Adult PBT were fed six days a week with a mixture of mackerel, jack mackerel, sardine and squid at a rate of 2 - 3\% of body weight. SBT have also been the subject of grow out/fattening trials in South Australia over a number years (Jeffriess, 1993; Lee, 1998; Carter et al., 1998). In one of the earliest trials at Kinki University in Japan, wild-caught PBT showed very good growth rates, averaging $20 \mathrm{~kg} \mathrm{year}^{-1}$, on a diet consisting of fish including mackerel, anchovy and sand eel (Harada et al., 1971). Subsequent trials elsewhere have used ground trash fish (Vincent, 1981) and a mixed diet of local mackerel, herring and butterfish for PBT, and locally caught and frozen pilchards/sardines for SBT (Fitz-Gerald, 1998).

Farming of small $(\sim 10 \mathrm{~kg})$ BFT in the Adriatic Sea used raw defrosted and/or fresh small pelagic fish such as sardines, herring, small mackerel and sprats. Fish were fed to satiation, six days per week and demonstrated relatively high growth rates (Tičina et al., 
2007). In the Mediterranean, capture-based aquaculture or fattening operations of large NBT use some local fish production, although a large percentage of the feed fish is imported frozen from outside the region. The feed fish used includes small pelagic species such as anchovy (Engraulis encrasicolus), sardine (Sardina pilchardus), round sardinella (Sardinella aurita), herring, mackerels (Scomber spp.), horse mackerel (Trachurus spp.), capelin (Mallotus villosus), shad (Alosa alosa) and short-fin squid (Illex spp.). This practice can be considered as an environmental threat to local fish populations and ecosystems because of the systematic dumping in the Mediterranean marine ecosystems of thousands of tonnes of non-local exotic whole fish, which constitutes a significant risk of spreading new diseases to native fish populations, as has already occurred in Australian waters in relation to SBT fattening operations (Ward et al., 2001; Gaughan, 2002; Ottolenghi et al., 2004; Ottolenghi, 2008). In summary, in tuna fattening operations FCR are generally high for large fish and (15-20:1) and not so high for smaller fish (10-15:1), but as consequence heterothermy and constant swimming only a small fraction (5\%) of the energy input is used for body growth (Korsmeyer and Dewars, 2001; Ottolenghi, 2008).

\subsection{Artificial feeds}

Early experiments at Kinki University included some comparative dietary trials where juvenile PBT were fed four test diets comprising three single species fish diets (sand eel, anchovy and mackerel) and a mixed diet of minced mackerel with a dry commercial diet for yellowtail (Harada et al., 1983). The PBT on both the mackerel diet and the mixture diet showed high survival and had body compositions similar to wild fish. However, whereas the fish on the mackerel diet had the best growth rate, the mixture diet had a relatively poor growth rate. Perhaps surprisingly, the fish on the anchovy diet had the lowest survival, growth 
rate and fat content (Harada et al., 1983). In general, baitfish of various species have proved to be relatively good feed for either PBT and/or SBT, but with many risks associated (Clarke et al., 1997; Ottolenghi et al., 2004; Ottolenghi, 2008).

The current need to use a wide variety of baitfish in fattening/farming operations, which have a correspondingly wide range in quality, pointed to the necessity of developing artificial manufactured feeds to replace the use of baitfish (Montague, 2003). It is not the quantity of baitfish supplied to the tuna, but the content and quality of its nutrients that influences production. If baitfish is low in protein and fat, tuna FCR will be high and growth rate low, and higher quantities of baitfish will be required to maintain the same production level. The characteristics and gross composition of the baitfish are quite variable, and large variations have been observed in the contents of crude protein (49.4\%-75.3\% dry mass), crude fat $(1.9 \%-36.5 \%$ dry mass $)$, free fatty acids $(2.9 \%-53.4 \%$ dry mass $)$ and peroxide value $(0.1 \mathrm{meg} / \mathrm{kg}-598.0 \mathrm{meg} / \mathrm{kg}$ dry mass) (www.sardi.sa.gov.au; Ottolenghi et al., 2004; Ottolenghi, 2008). Moreover, raw fish diets give disadvantages such as high FCRs, risks of pollution and disease, plus a high fishery pressure because of the demand. In spite of all the above, the necessity to formulate and manufacture artificial diets has generally been avoided due to various reasons including a desire to use fish derived from local or other commercially available fisheries including trash fisheries, high feed production costs, and a non enthusiastic Japanese market for tuna reared on pelleted food (Ottolenghi et al., 2004; Ottolenghi, 2008).

Dry and moist pellets have been trialled in studies with SBT in South Australia (Smart, 1995, 1996, 1998). The fish did not accept dry pellets, but pellets (sausage) containing $40 \%$ moisture and based on fishmeal and fish oil were readily accepted. The pellets were $40 \%$ protein with lipid levels varying between $7.5 \%$ and $12.5 \%$. Growth on the pellets (in combination with bait fish) was similar to that on baitfish (sardines) alone with feed conversions slightly better for pellets (Smart, 1995, 1996, 1998). Therefore, under 
research conditions, growth performance of SBT fed moist diets was similar to that of fish fed baitfish (Glencross et al., 1999a, 2002). Although weaning on to moist diets has been particularly successful at the initial phases of the production cycle when the fish feed extremely vigorously, the development of a dry manufactured diet has been limited due to problems encountered in weaning juvenile SBT on to dry artificial diets (Glencross et al., 2002). Most practical diet formulations for tuna have been based on muscle and/or natural prey species compositions (Smart et al., 2003), resulting in a high protein, high energy, low carbohydrate diet as befits a carnivore and opportunistic predator. In a new effort to develop an artificial diet for juvenile PBT, recent studies have shown the utility of diets formulated with enzyme-treated fish meal (to improve protein digestibility) and fortified bonito oil (10\% DHA-enriched oil) versus trash fish (sand lance) (Ji et al., 2008). However, although similar growth rates were obtained, the artificial diet led to a higher carcass lipid content, but lower accumulation of n-3 lc-PUFA.

In conclusion, considerably more studies and effort are required to develop new artificial diets and feeding technologies for tuna, which permit better SGRs and FCRs, flesh quality, reduced production costs and mitigate the problems and risks associated with the use of baitfish (Ottolenghi, 2008).

\subsection{Feeding practices}

Tuna feeding practices have been primarily developed to simultaneously accommodate the tuna's huge appetite, while minimizing the labour effort required (Glencross et al., 2002). However, feeding practices vary and depend on the type of food offered to fish. In any case, feeding activity is usually regulated by visual assessment (divers, underwater surveillance cameras) determining the feeding performance and estimating feed losses on the floor of the 
sea cages. Research regarding feeding frequency has shown that feeding tuna 7 days a week does not result in significantly higher growth rates or better condition factors than a feeding strategy in which the fish are fed 5 or 6 days a week. Thus, most farmers feed 5 - 6 days a week during the summer growing season and less during the winter.

When feeding with baitfish, SBT have generally shown a preference for clupeoids while other species of fish have been used with varying degree of success. Baitfish is fed to tunas after thawing or in frozen blocks by hand, shovelling or pumps. Feed intakes of tuna fed baitfish vary seasonally (Glencross et al., 2002). During periods of high water temperatures (above $20{ }^{\circ} \mathrm{C}$ ), daily feed intake is commonly around $10-12 \%$ of total body weight, but intakes as high as $15 \%$ have been reported. However, at lower water temperatures, feed intake is reduced to as low as $2 \%$ of body weight (Glencross et al., 2002). When feeding with pellet diets, rations are offered twice daily during the growing/fattening season and once daily during the later stages in response to lower feeding activities. Total intake of pelleted food is always less than that of baitfish, although it is greater on a dry-matter basis (Glencross et al., $1999 b ; 2002)$. Growth of PBT in captivity was higher than in the wild (Lee, 2003). Higher water temperature at the more in-shore grow-out sites can make a difference in weight gain since temperature strongly affects feeding activity, although there seems to be no difference over about $23^{\circ} \mathrm{C}$ (Masuma et al., 2008).

\section{FUTURE PERSPECTIVES AND GLOBAL CONSIDERATIONS}

The primary goals of research into the nutrition of large tunids such as BFT, PBT and SBT will be to define their precise nutritional requirements, and the development of ideal formulated artificial diets. This is required to remove the dependence of any prospective tuna aquaculture industry on whole fish feeds based on local and imported trash fish or individual 
species fisheries, such as anchovies or pilchards, which can be subject to great seasonal and environmental variations (Thorpe et al., 1997). However, it is very important to note that the current intense activities focussed on closing tuna life cycles and developing a large tunid aquaculture industry, growing fish from egg to market size, are taking place at a time when the aquaculture nutrition industry is currently going through great changes. These changes to feed formulations are considerable and are being forced upon the industry simply through the increasing expansion of aquaculture activities throughout the world that are rapidly outstripping global supplies of the principal dietary protein and oil sources, fish meal and oil. Based on our current knowledge of marine fish nutrition, and of the market that cultured tuna will be competing in, any formulated feed, whether it be a pellet and/or sausage diet, will have to be dependent, to some extent upon global supplies of fish meal and fish oil. The consequences of dietary formulations using more sustainable alternatives to fish meal and oil will likely be effects on flesh quality in tuna that have greater market impact than in any other fish species.

\subsection{Aquaculture and wild capture fisheries}

The exploitation and, many would argue, over-exploitation of wild fisheries has meant that an increasing proportion of fish for human consumption is now provided by aquaculture, which has been expanding at around $10 \%$ per year over the last 15 years (Tidwell and Allan, 2002). Indeed, aquaculture has been the world's fastest growing food production sector over this period and it is projected to more than double over the next decade or so (Naylor et al., 2000). It is a supreme paradox that the diets traditionally used in aquaculture have been based on fish meals and oils, themselves derived from wild fisheries, specifically the feed-grade or "reduction" fisheries, as the predominant protein and lipid sources (Sargent and Tacon, 1999; 
Pike, 2005). This has been particularly the case in Europe, where intensive fish farming is based on carnivorous species, particularly salmonid and marine species. These species feed high up in the food web and the large tunids represent the apex in this chain. However, the wild capture fisheries, whether for food- or feed-grade fish, are finite resources that, although potentially renewable, are highly vulnerable so that their sustainability is in question (Worm et al., 2006). Global capture fisheries have shown little growth over the last 20 years and currently yield less than 100 million tonnes per annum (FAO, 2006). Over exploitation (fishing) of individual fish species, whether for direct human consumption or reduction to fishmeal and fish oil, has caused the collapse or near collapse of some valuable fisheries (Worm et al., 2006). Environmental pressure groups are relentless in their aim to further reduce fishing effort and catches by introducing tighter regulatory measures. The increasing realisation that global warming and natural climatic events such as "El Niño" can profoundly affect major fisheries, especially the southern Pacific anchovy fishery, highlights the inherent vulnerability of global fisheries.

Stagnation of global fisheries along with all the other negative factors predicted that future demand for marine raw materials would exceed global supply leading to price increases and market instability. For example, the last major "El Niño" event resulted in the cost of fish oil increasing substantially from 1997 to 1998 to exceed that of soybean oil and, more recently, the cost of fish oil virtually doubled between October 2006 and the end of 2007. However, the rapidly increasing demand for marine raw products will have an even more profound consequence than price increases and instability, as current estimates indicate that the supply requirements for aquaculture feeds will exceed global supplies of fish oil and fishmeal within the next two to eight years, respectively (FAO, 2006). It has therefore been clear to the European aquaculture industry over the last few years that, for aquaculture to continue to expand and supply more of the global demand for fish, alternatives to fish oil and 
meal had to be found (Barlow, 2000; Tacon, 2004). The only obvious, and sustainable, alternatives to the marine raw materials are plant-derived products, specifically plant meals and vegetable oils (Sargent et al., 2002). The subject of fish oil and meal replacement in diets for salmonids and marine fish was the subject of a recent European Union (EU) Framework Programme 5 Network of Excellence, Fish Oil and Meal Replacement (FORM; Q5TN-200200628) (www.FORMNetwork.net), and is currently being researched in a large EU Framework Programme 6 Integrated Project, Sustainable Aquafeeds to Maximise the Health Benefits of Farmed Fish for Consumers (AQUAMAX; 016249) (www.aquamaxip.eu).

\subsection{Fish meal}

Declining and erratic global fisheries and rapidly increasing aquaculture as described above have to be considered against the background that fishmeal and fish oil are currently the major feedstocks for cultured marine fish. The protein component of aquaculture diets, is the single most important and expensive dietary component, especially for marine fish that tend to have higher dietary protein requirements than freshwater fish or salmonids (Wilson, 2002). At present, fishmeal remains the major dietary protein source, comprising between $20 \%$ and $60 \%$ of fish diets in general (Watanabe, 2002). The dietary requirement of farmed marine fish for high quality protein, rich in essential amino acids, can possibly be met by sources other than fishmeal. However, whereas fishmeal provides adequate supplies of all essential amino acids, some, such as lysine and methionine, are generally deficient in plant sources (Naylor et al., 2000). Among the various protein sources available for fish feeds, defatted soybean meal is generally accepted, both qualitatively and quantitatively. As well as having a favourable amino acid profile compared with other plant protein sources, soybean meal is consistently available, cost-effective and reported to be palatable to most fish species 
(Watanabe, 2002). Other common plant protein products include wheat and corn glutens, and pulses such as peas and beans. Soybeans, and other plant products can contain a number of anti-nutritional factors though, including trypsin inhibitors and phytic acid, that must be taken into account when plant proteins are utilized in feeds (Hardy and Barrows, 2002). However, considering the relatively wide range of plant protein alternatives available, blending various plant protein sources is usually a viable option, as is the use of protein concentrates and amino acid supplements. The replacement of fishmeal with plant proteins in diets for rainbow trout and the marine fish, gilthead sea bream, was recently the subject of a major EU Framework Programme 5 RTD research project, Perspectives of Plant Protein Use in Aquaculture (PEPPA; Q5RS-2000-30068) (www.st-pee.inra.fr/ici/stpee/nut/peppa/peppa).

There are few, if any, specific studies on fishmeal replacement in diets for tunids. However, the digestibility of alternative proteins has been investigated using a soft dry pelleted diet in the yellowtail, a marine pelagic species, obtaining digestibility values of $86 \%$ in diets containing from $30 \%$ to $50 \%$ soybean meal as protein source (Watanabe et al., 1992; Watanabe, 2002). Furthermore, and as explained above (section 3.2), in vitro studies of digestibility of key feed ingredients (fish meal, squid meal, casein, wheat gluten, soybean meal, wheat flour and pilchards) by SBT digesta enzymes has resulted in the refinement of moist diet development for this species and the results, in a practical approach, could be extrapolated to other tunids (Carter et al., 1998, 1999; Brandsen et al., 1999; Glencross et al., 2002).

\subsection{Fish oil}

Lipid (oil or fat) is included in dietary formulations not only as a very effective energy source, but also as a source of EFA. Thus, a major role of marine fish oils in aquaculture diets is as a 
source of the lc-PUFA, ARA, EPA and DHA, which together can satisfy the EFA requirements of all fish species (Tocher, 2003). Stagnation in feed-grade fish catches has also resulted in a shortage of fish oil (FAO, 2006). Indeed it is the limited global supply of fish oil rather than fishmeal that is the more serious problem, for at least two reasons. Firstly, it is far more imminent and shortages are already causing problems in the aquaculture feed industry, whereas fishmeal will not be limiting for a few more years (FAO, 2006). Secondly, as indicated above, there are a number of alternative protein sources and strategies for the replacement of fishmeals, whereas there are no ideal substitutes for marine fish oils. Currently, vegetable oils are the only sustainable, cost effective alternative lipid source for aquaculture diets and a number have been used as partial and complete replacements for fish oil (Bell et al., 2005). The replacement of fish oil with vegetable oils in diets for the salmonids, Atlantic salmon and rainbow trout, and the marine species, gilthead sea bream and European sea bass was recently the subject of a major EU Framework Programme 5 RTD research project, Researching Alternatives to Fish Oil in Aquaculture (RAFOA; Q5RS-200030058) (www.rafoa.stir.ac.uk).

Vegetable oils, rich in LOA and LNA are able to substitute for lc-PUFA in feeds for freshwater and salmonid fish without compromising growth performance or feed efficiency but, as described above, marine fish have an absolute dietary requirement for the preformed lc-PUFA for optimal growth and development and so, currently, there is no feasible alternative source to fish oil for these nutrients in marine fish feeds. Therefore, the use of vegetable oils in feeds for marine fish must be in combination with marine oils in sufficient amounts to satisfy the EFA requirement (Bell et al., 2005; Bell and Waagbø, 2008). Again, as previously indicated, the EFA requirements of tunids at all developmental stages remain unknown. However, even with freshwater and salmonid species, the use of vegetable oil is not without consequences. As vegetable oils are devoid of n-3 lc-PUFA, they can have a major 
impact on the fatty acid composition of the flesh if added at high inclusion levels (Bell and Waagbø, 2008). Decreased levels of the n-3 lc-PUFA, EPA and DHA, and increased levels of LOA and LNA can compromise the nutritional quality of the flesh (Bell et al., 2005). For that reason, some studies have investigated the use of "finishing diets" containing fish oil to restore levels of n-3 lc-PUFA in the flesh (Bell et al., 2003a,b; Bell et al., 2004; Robin et al., 2003; Caballero et al., 2004; Izquierdo et al., 2005; Mourente et al., 2005, 2006; Torstensen et al., 2005). The large tunid market demands very high flesh quality standards suggesting that major changes in flesh fatty acid composition in farmed tuna may not be acceptable. It is debatable that a finishing diet strategy could be successful with fish with a very large market size. At lower inclusion levels, dietary vegetable oils have correspondingly less impact on flesh fatty acid compositions (Robin et al., 2003). Therefore, an alternative to finishing diets could be the use of lower levels of fish oil substitution, particularly if the vegetable oil and fish oil blends used are carefully chosen to limit lc-PUFA reduction in the flesh (Torstensen et al., 2004). For instance, South American fish oils contain higher levels of n-3 lc-PUFA and so can deliver similar levels of n-3 lc-PUFA at lower inclusion levels than the North Atlantic fish oils most commonly used in diets (Sargent et al., 2002). However, tunids are characterised by high DHA:EPA ratios whereas the South American fish oils are characterised by rather low DHA:EPA ratios and so this strategy may also have negative impacts. As with fishmeal replacement, fish oil substitution is virtually unstudied in tunid-like species. In studies with yellowtail in Japan, it was shown that $50-60 \%$ of fish oil could be replaced by palm oil in soft dry pellet and extruded dry diets (Watanabe, 2002).

In conclusion, the effects of partial substitution of dietary fish oil with vegetable oils in diets for large tunids could have consequences for growth and health of the fish, as well as being potentially undesirable in terms of both consumer acceptance and human nutrition because of dilution of the health promoting effects of fish oil-derived EPA and DHA. This is 
a problem that can be projected to have potentially major consequences for tuna farming in the future and it would be advisable that plans for prospective tuna farming industries should address this problem at an early stage.

\section{REFERENCES}

Ackman, R. G. Fish Lipids, Part 1, pp. 86-103. In: Advances in Fish Science and Technology, (Connell, J. J., Ed.), Fishing News Books, Surrey, UK (1980).

Aguado, F., F. J. Martinez, and B. Garcia-Garcia. In vivo total nitrogen and total phosphorous digestibility in Atlantic bluefin tuna (Thunnus thynnus thynnus Linnaeus, 1758) under industrially intensive fattening conditions in Southeast Spain Mediterranean coastal waters. Aquacult. Nutr., 10: 413-419 (2004).

Aitken, D. E. Aquaculture in Atlantic Canada, pp. 6-15. In: Proc. Natl. Aquacult. Conf. Strategies for Aquacult. Develop. Canada. DFO Sci. Inf. Publ. Br., no. 75, DFO, Ottawa, Canada, (1984).

Barlow, S. Fishmeal and fish oil: sustainable ingredients for aquafeeds. Glob. Aquacult. Advocate, 4: 85-88 (2000).

Bell, M. V., R. S. Batty, J. R. Dick, K. Fretwell, J. C. Navarro, and J. R. Sargent. Dietary deficiency of docosahexaenoic acid impairs vision at low light intensities in juvenile herring (Clupea harengus L.). Lipids, 30: 443-449 (1995).

Bell, J. G., R. J. Henderson, D. R. Tocher, and J. R. Sargent. Replacement of dietary fish oil with increasing levels of linseed oil: Modification of flesh fatty acid compositions in Atlantic salmon (Salmo salar) using a fish oil finishing diet. Lipids, 39: 223-232 (2004).

Bell, J.G., F. McGhee, P. J. Campbell, and J. R. Sargent Rapeseed oil as an alternative to marine fish oil in diets of post-smolt Atlantic salmon (Salmo salar): changes in flesh 
fatty acid composition and effectiveness of subsequent fish oil "wash out". Aquaculture, 218: $515-528(2003 a)$.

Bell, J.G., D. R. Tocher, R. J. Henderson, J. R. Dick, and V. O. Crampton. Altered Fatty Acid Compositions in Atlantic Salmon (Salmo salar) Fed Diets Containing Linseed and Rapeseed Oils Can Be Partially Restored by a Subsequent Fish Oil Finishing Diet. $J$. Nutr., 133: 2793-2801 (2003b).

Bell, G., B. Torstensen, and J. R. Sargent. Replacement of marine fish oils with vegetable oils in feeds for farmed salmon. Lipid Technol., 17: 7-11 (2005).

Bell, J. G., and R. Waagbø. Safe and Nutritious Aquaculture Produce: Benefits and Risks of Alternative Sustainable Aquafeeds, pp. 185-225. In: Aquaculture in the Ecosystem, (Holmer M., K. D. Black, C. M. Duarte, N. Marba, and I. Karakassis, Eds.), Springer Verlag BV, (2008).

Belle, S. Work advances in bluefin tuna aquaculture. Fish Farm. News, 2: 1-9 (1994).

Benitez-Santana, T., R. Masuda, E. J. Carrillo, E. Ganuza, A. Valencia, C. M. HernandezCruz, and M. S. Izquierdo. Dietary n-3 HUFA deficiency induces a reduced visual response in gilthead seabrem Sparus aurata larvae. Aquaculture, 264: 408-417 (2007).

Biswas, A. K., J. Nozaki, M. Kurata, K. Takii, H. Kumai, and M. Seoka. Effect of Artemia enrichment on the growth and survival of Pacific bluefin tuna Thunnus orientalis (Temminck et Schlegel) larvae. Aquacult. Res., 37: 1662-1670 (2006).

Blank, J. M., C. J. Farwell, J. M. Morrissette, R. J. Schallert, and B. A. Block. Influence of Swimming Speed on Metabolic Rates of Juvenile Pacific Bluefin Tuna and Yellowfin Tuna. Physiol. Biochem. Zool., 80: 167-177 (2007).

Brandsen, M. P., C. G. Carter, and B. F. Nowak. Atlantic salmon (Salmo salar) as a surrogate species for the development of an artificial diet for the southern bluefin tuna (Thunnus 
maccoyii), pp. 99. In: Proceedings of the World Aquacult. Soc., World Aquaculture Society, Sidney, Australia, (1999).

Buchanan, L. Ranching Atlantic bluefin. Sea Front., 23: 172-180 (1977).

Buddington, R. K., and A. Krogdahl. Hormonal regulation of the fish gastrointestinal tract. Comp. Biochem. Physiol., A, 139: 261-271 (2004).

Caballero, M.J., M. S. Izquierdo, E. Kjorsvik, A. J. Fernandez, and G. Rosenlund. Histological alterations in the liver of sea bream, Sparus aurata L., caused by short- or long-term feeding with vegetable oils. Recovery of normal morphology after feeding fish oil as the sole lipid source. J. Fish Dis., 27: 531-541 (2004).

Carey, F.G., J. W. Kanwisher, and E. D. Stevens. Bluefin tuna warm their viscera during digestion. J. Exp. Biol., 109: 1-20 (1984).

Carter, C.G., G.S. Seeto, A. Smart, S. Clarke, and R.J. van-Barneveld. Correlates of growth in farmed juvenile southern bluefin tuna Thunnus maccoyii (Castelnau). Aquaculture, 161: 107-119 (1998).

Carter, C. G., M. P. Brandsen, R. J. van Barneveld, and S. M. Clarke. Alternative methods for nutrition research on the southern bluefin tuna, Thunnus maccoyii (Castenau): in vitro digestibility. Aquaculture, 179: 57-70 (1999).

Chase, B. C. Differences in diet of Atlantic bluefin tuna (Thunnus thynnus) at five seasonal feeding grounds on the New England continental shelf Fish. Bull., 100: 168-180 (2002).

Clarke, S., A. Smart, R. van Barneveld, and C. Carter. The development and optimisation of manufactured feeds for farmed southern bluefin tuna. Austasia Aquaculture, 11: 59-62 (1997).

Clay, D. Fat, water, protein and ash of bluefin tuna collected in the Gulf of St. Lawrence. ICCAT Coll. Vol. Sci. Pap., 28: 196-202 (1988). 
Conceição, L.E.C., S. Morais, and I. Rønnestad. Tracers in fish larvae nutrition: A review of methods and applications. Aquaculture, 267: 62-75 (2007).

Cowey, C. B. The nutrition of fish: The developing scene. Nutr. Res. Rev., 1: 255-280 (1988).

Cowey, C. B., and J. R. Sargent. Nutrition, pp. 1-69. In: Fish Physiology Vol. VIII, (Hoar, W. S., D. J. Randall, and J. R. Brett, Eds.), Academic Press, New York, (1979).

Davis, B. J. Assessment of protein and digestibility in caged southern bluefin tuna (SBT) fed manufactured diets. B. App. Sc. (Agriculture) (Hons) Thesis, The University of Adelaide, Australia (1997).

Doumenge, F. Aquaculture of bluefin tuna. Biol. Mar. Mediterr., 3: 258-288 (1996).

Dragovich, A. The Food of Bluefin Tuna (Thunnus thynnus) in the Western North Atlantic Ocean. Trans. Am. Fish. Soc., 99: 726-731 (1970).

Eggleston, D. B., and E. Bochenek. Stomach contents and parasite infestation of school bluefin tuna Thunnus thynnus collected from the Middle Atlantic Bight, Virginia Fish. Bull., 88: 389-395 (1990).

FAO (Food and Agricultural Organisation). FAO Fisheries Technical paper No. 500., 134 pp. FAO, Rome (2006).

Fernandez, I., F. Hontoria, J. B. Ortiz-Delgado, Y. Kotzamanis, A. Estevez, J. L. ZamboninoInfante, and E. Gisbert. Larval peformance and skeletal deformities in farmed gilthead sea bream (Sparus aurata) fed with graded levels of vitamin A enriched rotifers (Brachionus plicatilis).. Aquaculture, 283, 102-115 (2008).

Fitz-Gerald, C. H., and H. A. Bremner. The oxidative stability of chilled and frozen pilchards used as feed for captive southern bluefin tuna. J. Aquat. Food Prod. Technol., 7: 27-44 (1998). 
Fitzgibbon, Q.P., R. V. Baudinette, R. J. Musgrove, and R. S. Seymour. Routine metabolic rate of southern bluefin tuna (Thunnus maccoyii). Comp. Biochem. Physiol. A, 150: 231238 (2008).

Fitzgibbon, Q.P., R. S. Seymour, D. Ellis, and J. Buchanan. The energetic consequence of specific dynamic action in southern bluefin tuna Thunnus maccoyii. J. Exp. Biol., 210: 290-298 (2007).

Fushimi, H., K. Kani, H. Nhhala, S. Nakamura, A. Abrouch, K. Chebaki, and A. Berraho. Attempt on resources enhancement of Atlantic bluefin tuna, present status and future perspectiveof Japanese-Moroccan cooperative project for aquaculture of Atlantic bluefin tuna. In: Symposium ICCAT (PATR Contribution $n^{o} 8$ ); 10-18 June, Ponta Delgada, Azores, Portugal (1996).

Gaughan, D.J. Disease translocation across geographic boundaries must be recognized as a risk even in the absence of disease identification: The case with Australian Sardinops. Rev. Fish Biol. Fisheries, 11: 113-123 (2002).

Glencross, B. D., R. J. van Barneveld, C. G. Carter, and S. M. Clarke. On the path to a munufactered feed for farmed bluefin tuna. World Aquaculture Magazine, 30(3): $42-46$ (1999a).

Glencross, B. D., R. J. van Barneveld, C. G. Carter, and S. M.Clarke. Factors influencing feed intake and feed conversion in farmed southern bluefin tuna (Thunnus maccoyii), pp. 287. In: Proc. World Aquacult. Soc., NSW Fisheries, Sydney, Australia, (1999b).

Glencross, B. D., C. G. Carter, J. Gunn, R. J. van Barneveld, K. Rough, and S. M. Clarke. Southern bluefin tuna, Thunnus maccoyii, pp. 159-171. In: Nutrient Requirements and Feeding of Finfish for Aquaculture, (Webster, C. D. And C. Lim, Eds.) CABI Publishing, New York, USA (2002). 
Glencross, B. D., M. Booth, and G. L. Allan. A feed is only as good as its ingredients - a review of ingredient evaluation strategies for aquaculture feeds. Aquaculture Nutr., 13: 17-34 (2007).

Graham, J. B., and K. A. Dickson. Tuna comparative physiology. The Journal of Experimental Biology, 207: 4015-4024 (2004).

Halver, J.E. The Vitamins, pp. 61-141. In: Fish Nutrition $3^{\text {rd }}$ Edition. (Halver J. E. and R.W. Hardy, Eds.), Academic Press, San Diego, (2002).

Harada, T., H. Kumai, K. Mizuno, and O. Murate. On the rearing of young bluefin tuna. Mem. Fac. Agr. Kinki Univ., 4: 153-157 (1971).

Harada, T., O. Murate, and T. Norita. The effects resulting from certain diets in young bluefin tuna, Thunnus thynnus. Mem. Fac. Agr. Kinki Univ., 16: 59-65 (1983).

Hardy, R. W. and F. T. Barrows. Diet formulation and manufacture, pp. 505-600. In: Fish Nutrition $3^{\text {rd }}$ Edition. (Halver J. E. and R. W. Hardy, Eds.), Academic Press, San Diego, (2002).

Hiratsuka, S., T. Kitagawa, K. Yamagishi, and S. Wada. Phospholipase $\mathrm{A}_{1}$ activity of crude enzyme extracted from the ovaries of skipjack tuna. Fish. Sci., 74: 146-152 (2008).

Holliday, M. Food of Atlantic Bluefin Tuna, Thunnus thynnus (L.), from the Coastal Waters of North Carolina to Massachusetts. M.Sc. thesis. Long Island Univ., Long Island, NY, (1978).

Houlihan, D.F., I. D. McCarthy, C. G. Carter, and P. Martin. Protein turnover and amino acid flux in fish larvae, pp 87-99. In: Proceedings ICES Marine Science Symposium 201, (1995).

Ishihara, K., and H. Saito. The docosahexaenoic acid content in the lipid of juvenile bluefin tuna Thunnus thynnus caught in the sea of the Japanese coast. Fish. Sci., 62: 840-841 (1996). 
Ishizaki, Y., R. Masuda, K. Uematsu, K. Shimizu, M. Arimoto, and T. Takeuchi. The effect of dietary docosahexaenoic acid on schooling behaviour and brain development in larval yellowtail. J. Fish Biol., 58: 1691-1703 (2001).

Izquierdo, M.S. Essential fatty acid requirements in Mediterranean fish species. Cah. Options Mediterr., 63: 91-102 (2005).

Izquierdo, M.S., H. Fernandez-Palacios, and A. G. J. Tacon. Effect of broodstock nutrition on reproductive performance of fish. Aquaculture, 197: 25-42 (2001).

Izquierdo, M.S., D. Montero, L. Robaina, M. J. Caballero, G. Rosenlund, and R. Ginés. Alterations in fillet fatty acid profiles and flesh quality in gilthead seabream (Sparus aurata) fed vegetable oils for a long term period. Recovery of fatty acid profiles by fish oil feeding. Aquaculture, 250: 431-444 (2005).

Jeffriess, B. Developments in farming southern bluefin tuna, pp. 124-127. In: Infofish Tuna Trade Conference, Bangkok, Thailand, (de Saram H., and N. Krishnasamy, Eds.), Infofish, Kuala Lumpur, (1993).

Ji, S., O. Takaoka, A. Biswas, M. Seoka, K. Ozaki, J. Kohbara, M. Ukawa, S. Shimeno, H. Hosokawa, and K. Takii. Dietary utility of enzyme-treated fish meal for juvenile Pacific bluefin tuna Thunnus orientalis. Fish. Sci., 74: 54-61 (2008).

Jobling, M. Fish Bioenergetics. Fish and Fisheries Series 13, 309 pp. Chapman and Hall, London (1994).

Kaji, T. Studies on the early development of bluefin and yellowfin tuna. Ph D Thesis, Kyoto University, Japan (2002).

Kaji, T., M. Kodama, H. Arai, M. Tawaka, and M. Tanaka. Precocious development of the digestive system in relation to early appearance of piscivory in striped bonito Sarda orientalis larvae. Fish. Sci., 68: 1212-1218 (2002). 
Kaji, T., M. Tanaka, Y. Takahashi, M. Oka, and N. Ishibashi. Preliminary observations on development of Pacific bluefin tuna Thunnus thynnus (Scombridae) larvae reared in the laboratory, with special reference to the digestive system. Mar. Freshwater Res., 47: 261-269 (1996).

Kaji, T., M. Tanaka, M. Oka, H. Takeuchi, S. Oshumi, K. Teruya, and J. Hirokawa. Growth and morphological development of laboratory-reared yellowfin tuna Thunnus albacares larvae and early juveniles, with special emphasis on the digestive system. Fisheries Sci., 65: 700-707 (1999).

Kitchell, J. F., W. H. Neill, A. E. Dizon, J. J. Magnusson. Bioenergetic spectra of skipjack and yellowfin tunas, pp. 357-368, In: The Physiologycal Ecology of Tunas. (Sharp G. D. and A. E. Dizon, Eds.), Academic Press, New York, (1978).

Kohbara, J., T. Miyazaki, K. Takii, H. Hosokawa, M. Ukawa, and H. Kumai. Gustatory responses in Pacific bluefin tuna Thunnus orientalis (Temmink and Schlegel). Aquacult. Res., 37: 847-854 (2006).

Korsmeyer, K. E. and H. Dewars. Tuna metabolism and energetic. Fish Physiology Series Vol. 19, pp 3-78. In: Tuna: Physiology, Ecology and Evolution. (Block B. A. and E. D. Stevens, Eds.). Academic Press, San Diego, CA, USA. (2001).

Lee, C.-S. Biotechnological advances in finfish hatchery production: a review. Aquaculture, 227: 439-458 (2003).

Lee, D. C. A study on the feasibility of the aquaculture of the southern bluefin tuna Thunnus maccoyii. Report for Department of Agriculture Fisheries and Forestry Australia (AFFA), Fisheries, Government of Western Australia, Broome, Australia, 91 pp., (1998).

Lucas, A. Bioenergetics of Aquatic Animals. Taylor and Francis, London, 169 pp. (1996) 
Masuda, R., T. Takeuchi, T. Tsukamoto, Y. Ishizaki, M. Kanematsu, and K. Imaizumi. Critical involvement of dietary docosahexaenoic acid in the ontogeny of schooling behaviour in the yellowtail. J. Fish Biol., 53: 471-484 (1998).

Masuda, R., D. A. Ziemann, and A. C. Ostrowski. Patchiness Formation and Development of Schooling Behavior in Pacific Threadfin Polydactylus sexfilis Reared with Different Dietary Highly Unsaturated Fatty Acid Contents. J. World Aquacult. Soc., 32: 309-316 (2001).

Masuma, S., S. Miyashita, H. Yamamoto, and H. Kumai. Status of Bluefin Tuna Farming, Broodstock Management, Breeding and Fingerling Production in Japan. Rev. Fisheries Sci., 16: 385-390 (2008).

Masumoto, T. Yellowtail, Seriola quinqueradiata, pp. 131-146. In: Nutrient Requirements and Feeding of Finfish for Aquaculture, (Webster, C. D. and C. Lim, Eds.) CABI Publishing, New York, USA (2002).

Matus de la Parra, A., A. Rosas, J. P. Lazo, and M. T. Viana. Partial characterization of the digestive enzymes of Pacific bluefin tuna Thunnus orientalis under cultura conditions. Fish Physiol. Biochem., 33: 223-231 (2007).

Medina, I., S. P. Aubourg, and R. P. Martin. Composition of phospholipids of white muscle of six tuna species. Lipids, 30: 1127-1135 (1995).

Miyashita, S., K. Kato, Y. Sawada, O. Murata, Y. Ishitani, K. Shimizu, S. Yamamoto, and H. Kumai. Development of digestive system and digestive enzyme activities of larval and juvenile bluefin tuna, Thunnus thynnus, reared in the laboratory. Suisanzoshoku, 46(1): 111-120 (1998).

Miyashita, S., Y. Sawada, N. Hattori, H. Nakatsukasa, T. Okada, O. Murata, and H. Kumai. Mortality of northern bluefi $\mathrm{n}$ tuna (Thunnus thynnus) due to trauma caused by collision during growout culture. J. World Aquacult. Soc., 31: 632- 642 (2000). 
Montague, P. Australian southern bluefin tuna farming and research activity - national report. Cahiers Options Méditerranéennes, 60: 139-141 (2003).

Mourente, G. Accumulation of DHA (docosahexaenoic acid; 22:6n-3) in larval and juvenile fish brain, pp. 239-248. In: The Big Fish Bang., ( Browman H., and A. B. Skiftesvik, Eds.) Published by the Institute of Marine Research, Postboks 1870 Nordes, N-5817, Bergen, Norway,( 2003).

Mourente, G., and J. G. Bell. Partial replacement of dietary fish oil with blends of vegetable oils (rapeseed, linseed and palm oils) in diets for European sea bass (Dicentrarchus labrax, L.) over a long term growth study: effects on flesh and liver fatty acid composition and effectiveness of a fish oil finishing diet. Comp. Biochem. Physiol. B, 145: 389-399 (2006).

Mourente, G., J. E. Good, and J. G. Bell. Partial substitution of fish oil with rapeseed oil, linseed oil and olive oil in diets for European sea bass (Dicentrarchus labrax L.): effects on flesh fatty acid composition, plasma prostaglandins $\mathrm{E}_{2}$ and $\mathrm{F}_{2 \forall}$, immune function and effectiveness of a fish oil finishing diet. Aquacult. Nutr., 11: 25-40 (2005).

Mourente, G., and D. R. Tocher. Lipid class and fatty acid composition of brain lipids from Atlantic herring (Clupea harengus, L.) at different stages of development. Mar. Biol., 112: $553-558(1992 a)$.

Mourente, G., and D. R. Tocher. Effects of weaning onto a pelleted diet on docosahexaenoic acid (22:6n-3) levels in brain of developing turbot (Scophthalmus maximus, L.). Aquaculture, 105: 363-377 (1992b).

Mourente, G. and D. R. Tocher. Effect of weaning on to a dry pellet diet on brain lipid and fatty acid compositions in postlarvae of gilthead sea bream (Sparus aurata, L.). Comp. Biochem. Physiol. A., 104(3): 605-611 (1993). 
Mourente, G., D. R. Tocher, and J. R. Sargent. Specific accumulation of docosahexaenoic acid (22:6n-3) in brain lipids during development of juvenile turbot Scophthalmus maximus L. Lipids, 26(11): 871-877 (1991).

Murase, T., and H. Saito. The docosahexaenoic acid content in the lipid of albacore Thunnus alalunga caught in two separate localities. Fish. Sci., 62(4): 634-638 (1996).

Nakagawa, Y., M. Eguchi, and S. Miyashita. Pacific bluefin tuna, Thunnus orientalis, larvae utilize energy and nutrients of microbial loop. Aquaculture, 267: 83-93 (2007).

Navarro, J.C., L. A. McEvoy, M. V. Bell, F. Amat, F. Hontoria, and J. R. Sargent. Effect of different dietary levels of docosahexaenoic acid (DHA, 22:6n-3) on the DHA composition of lipid classes in sea bass larvae eyes. Aquacult. Int., 5: 509-516 (1997).

Naylor, R.L., R. J. Goldburg, J. H. Primavera, N. Kautsky, M. C. M. Beveridge, J. Clay, C. Folke, J. Lubchenco, H. Mooney, and M. Troell. Effect of aquaculture on world fish supplies. Nature, 405: 1017-1024 (2000).

Nichols, P.D., P. Virtue, B. D. Money, N. G. Elliot, and G. K. Yearsley. Seafood the Good Food: The Oil (Fat) Content and Composition of Australian Commercial Fishes, Shellfishes and Crustaceans. CSIRO Marine Reseach, Hobart, Australia. (1998).

NRC (National Research Council). Nutrient Requirements of Fish, 114 pp. National Academy Press, Washington DC, (1993).

Okamoto, R., H. Matsunaga, K. Funae, and M. Hisaoka. Study on the rearing of young bluefin tuna Thunnus thynnus orientalis (Temminck et Schlegel) in Seto Inland Sea. Bull. Nansei Reg. Fish. Res. Lab. Nanseisuikenho, 17: 207-218 (1984).

O’ Sullivan, D. Farming the southern bluefin tuna. INFOFISH International, 6:39-46 (1993).

Ortiz de Zarate, V., and J. L. Cort. Stomach content study of immature bluefin tuna in the Bay of Biscay (Region 3 of EEC). ICES Report, 10 pp., ICES, Copenhagen Denmark (1986). 
Orsi-Relini, L., F. Garibaldi, C. Cima, and G. Palandri. Feeding of the swordfish, the bluefin and other pelagic nekton in the western Ligurian Sea. ICCAT Coll. Vol. Sci. Pap., 44: 283-286 (1995).

Ottolenghi, F. Capture-based aquaculture of bluefin tuna. pp. 169-182 In: Capture-based Aquaculture. Global Overview, FAO Fisheries Technical Paper $N^{o}$ 508. (Lovatelli, A. and P. P. Holtthus, Eds.). FAO, Rome (2008).

Ottolenghi, F., C. Silvestri, P. Giordano, A. Lovatelli, and M. B. New. Tunas, pp. 105-148. In: Capture-based aquaculture: The fattening of eels, groupers, tunas and yellowtails. FAO Publication, Rome, 308 p., (2004).

Pike, I. Eco-efficiency in aquaculture: global catch of wild fish used in aquaculture. International Aquafeed, 8: 38-40 (2005).

Robin, J., C. Regost, J. Arzel, and S. Kaushik. Fatty acid profile of fish following a change in dietary fatty acid source: model of fatty acid composition with a dilution hypothesis. Aquaculture, 225: 283-293 (2003).

Rønnestad, I., and H. J. Fyhn. Metabolic aspects of free amino acids in developing marine fish eggs and larvae. Rev. Fish. Sci., 1: 239-259 (1993).

Rønnestad, I., Y. Kamisaka, L. E. C. Conceição, S. Morais, and S. K. Tonheim. Digestive physiology of marine fish larvae: Hormonal control and processing capacity for proteins, peptides and amino acids. Aquaculture, 268: 82-97 (2007).

Rust, M.B. Nutritional Physiology, pp. 367-452. In: Fish Nutrition $3^{\text {rd }}$ Edition. (Halver J. E. and R.W. Hardy, Eds.), Academic Press, San Diego, (2002).

Sara, G., and R. Sara. Feeding habits and trophic levels of bluefin tuna Thunnus thynnus of different size classes in the Mediterranean sea. J. Appl. Ichthyol., 23: 122-127 (2007). 
Saito, H., K. Ishihara, and T. Murase. Effect of prey lipids on the docosahexaenoic acid content of total fatty acids in the lipids of Thunnus albacares yellowfin tuna. Biosci. Biotechnol. Biochem., 60: 962-965 (1996).

Sargent, J.R., J. G. Bell, M. V. Bell, R. J. Henderson, and D. R. Tocher. The metabolism of phospholipids and polyunsaturated fatty acids in fish, pp. 103-124. In: Aquaculture: Fundamental and Applied Research. (Lahlou, B. and P. Vitiello, Eds.), Coastal and Estuarine Studies, 43, American Geophysical Union, Washington, D.C, (1993).

Sargent, J. R., J. G. Bell, R. J. Henderson, and D. R. Tocher. Requirement criteria for essential fatty acids. J. Appl. Ichthyol., 11: 183-198 (1995).

Sargent, J.R., and A. Tacon. Development of farmed fish: a nutritionally necessary alternative to meat. Proc. Nutr. Soc., 58: 377-383 (1999).

Sargent, J. R., D. R. Tocher, and J. G. Bell. The Lipids, pp. 181-257. In: Fish Nutrition $3^{\text {rd }}$ Edition. (Halver J. E. and R.W. Hardy, Eds.), Academic Press, San Diego, (2002).

Sawada, T., T. Okada, S. Miyashita, O. Murata, and H. Kumai. Completion of the Pacific bluefin tuna Thunnus orientalis (Temminck et Schlegel) life cycle. Aquacult. Res., 36: 413-421 (2005).

Sawada, T., K. Takahashi, and M. Hatano. Triglyceride composition of tuna and bonito orbital fats. Nippon Suisan Gakkaishi, 59: 285-290 (1993).

Seoka, M., M. Kurata, and H. Kumai. Effect of docosahexaenoic acid enrichment in Artemia on growth of Pacific bluefin tuna Thunnus orientalis larvae Aquaculture, 270, 193-199 (2007).

Seoka, M., M. Kurata, R. Tamagawa, A. K. Biswas, B. K. Biswas, A. S. K. Yong, Y. Kim, S. Ji, K. Takii, and H. Kumai. Dietary supplementation of salmon roe phospholipid enhances the growth and survival of Pacific bluefin tuna Thunnus orientalis larvae and juveniles. Aquaculture, 275:, 225-234 (2008) 
Sinopoli, M., C. Pipitone, S. Campagnuolo, D. Campo, L. Castriota, E. Mostarda, and F. Andaloro. Diet of young-of-the-year bluefin tuna, Thunnus thynnus (Linnaeus, 1758), in the southern Tyrrenian (Mediterranean) Sea. J. Appl. Ichthyol., 20: 310-313 (2004).

Smart, A. Feed intake and growth of sea caged southern bluefin tuna Thunnus maccoyii (Castlenau). Tuna Farming Research Office, South Australian Research and Development Institute and Tuna Boat Owners Association of Australia (1995).

Smart, A. Feed intake and growth of sea-caged, southern bluefin tuna Thunnus maccoyii_Castelnau., fed manufactured diets. Master of Applied Science dissertation, University of Tasmania, Launceston (National Key Centre for Aquaculture) $23 \mathrm{pp}$. (1996).

Smart, A. Bluefin tuna aquaculture: Nutritional developments. International Aquafeed, 2: 2730 (1998).

Smart, A., P. C. Sylvia, and S. Belle. Nutritional management and development of manufactured feeds for tuna aquaculture. Cahiers Options Méditerranéennes, 60: 187$190(2003)$.

Tacon, A. G. J. Use of fish meal and fish oil in aquaculture: a global perspective. Aquatic Resources, Culture and Development, 1: 3-14 (2004).

Takii, K., S. Miyashita, M. Seoka, Y. Tanaka, Y. Kubo, and H. Kumai. Changes in chemical contents and enzyme activities during embryonic development of bluefin tuna. Fish. Sci., 63, 1014-1018 (1997).

Takii, K., H. Hosokawa, S. Shimeno, M. Ukawa, A. Kotani, and Y. Yamada. Anesthesia, fasting tolerance, and nutrient requierement of juvenile northern bluefin tuna. Fish. Sci., 71: $499-503$ (2005).

Tanabe, T. Feeding habits of skipjack tuna Katsuwonus pelamis and other Thunnus spp. juveniles in the tropical western Pacific. Fisheries Sci., 67: 563-570 (2001). 
Tanaka, Y., K. Satoh, H. Yamada, T. Takebe, H. Nikaido, and S. Shiozawa. Assessment of the nutritional status of field-caught larval Pacific bluefin tuna by RNA/DNA ratio based on a starvation experiment of hatchery-reared fish. J. Exp. Mar. Biol. Ecol., 354: 56-64 (2008).

Tanji, M. Kageyama, T. and K. Takahashi. Tuna pepsinogens and pepsins, purification, characterization and amino terminal sequences. Eur. J. Biochem., 177: 251-259 (1988).

Tanji, M., Yakabe, E., Kageyama, T. and K. Takahashi. The primary structure of the major pepsinogens from the gastric mucosa of tuna stomach. J. Biochem., 120: 647-656 (1996).

Tanji, M., Yakabe, E., Kubota, K., Kageyama, T., Ichinose, M., Miki, K., Ito, H. and K. Takahashi. Structural and phylogenetic comparison of three pepsinogens from Pacific bluefin tuna: molecular evolution of fish pepsinogens. Comp. Biochem. Physiol. B, 152: 9-19 (2009).

Thorpe, S., K. van Landeghem, L. Hogan, and P. Holland. Economic effects on Australian southern bluefin tuna farming of a quarantine ban on imported pilchards. ABARE Report to the Fisheries Resource Research Fund, Canberra, Australia (1997).

Tičina, V., I. Katavić, and L. Grubišić. Growth indices of small northern bluefin tuna (Thunnus thynnus, L.) in growth-out rearing cages. Aquaculture, 269: 538-543 (2007).

Tidwell, J.H., and G. L. Allan. Fish as food: aquaculture's contribution. Ecological and economic impacts and contributions of fish farming and capture fisheries. World Aquaculture, 33: 44-48 (2002).

Tocher, D. R. Metabolism and function of lipids and fatty acids in teleost fish. Review Fish. Sci., 11: 107-184 (2003).

Torstensen, B.E., J. G. Bell, G. Rosenlund, R. J. Henderson, I. E. Graff, D. R. Tocher, Ø Lie, and J. R. Sargent. Tailoring of Atlantic salmon (Salmo salar L.) flesh lipid 
composition and sensory quality by replacing fish oil with a vegetable oil blend. $J$. Agric. Fd. Chem., 53: 10166-10178 (2005).

Torstensen, B. E., L. Frøyland, R. Ørnsrud, and Ø. Lie. Tailoring of a cardioprotective muscle fatty acid composition of Atlantic salmon (Salmo salar) fed vegetable oils. Fd. Chem., 87: 567-580 (2004).

Uotani, I., K. Matsuzaki, Y. Makino, K. Noka, O. Inamura, and M. Horikawa.Food habits of larvae of tunas and their related species in the area northwest of Australia. Bull. Jap. Soc. Sci. Fish., 47: 1165-1172 (1981).

Uotani, I., T. Saito, K. Hiranuma, and Y. Nishikawa. Feeding habit of bluefin tuna Thunnus thynnus larvae in the western North Pacific Ocean. Nippon Suisan Gakkaishi, 56: 713$717(1990)$

van Barneveld, R. J., A. Smart, S. M. Clarke, C. G. Carter, B. J. Davis, D. R. Tivey, and J. D. Brooker. Nutritional management of sea-caged southern bluefin tuna (Thunnus maccoyii). In: Recent Advances in Animal Nutrition in Australia '97, pp. 88-97. (Corbett J. L., M. Choct, J. V. Nolan, and J. B. Rowe, Eds.), Department of Animal Science, University of New England, Armidale, Australia, (1997).

van der Meeren, T., R. E. Olsen, K. Hamre, and H. J. Fyhn. Biochemical composition of copepods for evaluation of fedd quality in production of juvenile marine fish. Aquaculture, 274: 375-397 (2008).

Vincent, P. L'élevage du thon rouge. Publ. CNEXO France Rapp. Sci. Tech., no. 47 : 71 (1981).

Volkoff, H., L. F. Canosa, S. Unniappan, J. M. Cerdá-Reverter, N. J. Bernier, S. P. Kelly, and R. E. Peter. Neuropeptides and the control of food intake in fish. Gen. Comp. Endocrinol., 142: 3-19 (2005). 
Ward, T.M., F. Hoetd, L. McLeay, W.F. Dimmlich, M. Kinloch, G. Jackson, R. McGarvey, P.J. Rogers, and K. Jones. Effects of the 1995 and 1998 mass mortality events on the spawning biomass of sardine, Sardinops sagax, in South Australian waters. ICES J. Mar. Sci., 58: 865-875 (2001).

Watanabe, T. Strategies for further development for aquatic feeds. Fisheries Sci., 68: $242-252(2002)$.

Watanabe, T., and R. Vassallo-Agius. Broodstock nutrition research on marine finfish in Japan. Aquaculture, 227: 35-61 (2003).

Watanabe, T., V. Viyakarn, H. Kimura, K. Ogawa, N. Okamoto, and N. Iso. Utilization of soybean meal as a protein source in a newly developed soft-dry pellet for yellowtail. Nippon Suisan Gakkaishi, 58: 1761-1773 (1992).

Wexler, J. B., V. P. Scholey, R. J. Olson, D. Margulies, A. Nakazawa, and J. M. Suter. Tank culture of yellowfin tuna, Thunnus albacares: developing a spawning population for research purposes. Aquaculture, 220: 327-353 (2003).

Wilson, R. P. Amino Acids and Proteins, pp. 143-179. In: Fish Nutrition $3^{\text {rd }}$ Edition. (Halver J. E. and R.W. Hardy, Eds.), Academic Press, San Diego, (2002).

Worm, B., E. B. Barbier, N. Beaumont, J. E. Duffy, C. Folke, B. S. Halpern, J. B. C. Jackson, H. K. Lotze, F. Micheli, S. R. Palumbi, E. Sala, K. A. Selkoe, J. J. Stachowicz, and R. Watson. Impacts of Biodiversity Loss on Ocean Ecosystem Services. Science, 314: 787-790 (2006).

Young, J.W., and T. L. O. Davis. Feeding ecology of larvae of southern bluefin, albacore, and skipjack tunas (Pisces: Scombridae) in the eastern Indian Ocean. Mar. Ecol. Prog. Ser., 61: 17-29 (1990).

Young, J. W., T. D. Lamb, D. L. Russel, R. W. Bradford, and A. W. Whitelaw. Feeding ecology and interannual variation in diet of southern bluefin tuna, 
Thunnus maccoyii, in relation to coastal and oceanic waters off eastern Tasmania, Australia. Environ. Biol. Fish., 50: 275-291 (1997). 